\title{
Evaluation of Japanese universities' research activity based on the number of awards of Grants-in-Aid for Scientific Research from 1998 to 2002 and in 2003
}

\author{
Masaki NISHIZAWA ${ }^{1}$, Masamitsu NEGISHI ${ }^{2}$, Morio SHIBAYAMA ${ }^{3}$, Yuan SUN ${ }^{4}$, \\ Hiroyasu NOMURA ${ }^{5}$, Masafumi MAEDA ${ }^{6}$ and Yoshitaka MITSUDA ${ }^{7}$ \\ 1,2,3,4 National Institute of Informatics \\ 1,2 The Graduate University for Advanced Studies (SOKENDAI) \\ ${ }^{5}$ Tokyo Denki University \\ 6,7 The University of Tokyo
}

\begin{abstract}
The system of Grants-in-Aid for Scientific Research from the Ministry of Education, Culture, Sports, Science and Technology (MEXT) is one of the oldest funding systems for researchers belonging to universities and institutes in Japan. The fund is allotted to researchers by peer review of their applications for research projects. The total number of subjects of Grantsin-Aid for Scientific Research allotted to the individual research fields from fiscal years (FY) 1998 to 2002 were tallied for each university and institute. The purpose of this report is to rank funded subjects as an index of the research activities of each university and institute. Furthermore, using the database for FY 2003, for which the ministry undertook a large revision to the classification of academic fields, we show the relationship between the situations before and after the classification changes. We indicate whether the last revision has caused significant shifts in the allocation of funds. This paper contains information abstracted from six series of NII Technical Reports from FY 1998 to 2002 and five series for FY 2003.
\end{abstract}

\section{KEYWORDS}

Japanese university, ranking, evaluation, Grants-in-Aid for Scientific Research

\section{Outline of Grants-in-Aid for Scienti?c Research}

1.1 History and budget growth

The system of Grants-in-Aid for Scientific Research from the Ministry of Education, Culture, Sports, Science and Technology (MEXT) is one of the oldest funding systems for researchers belonging to universities and institutes in Japan. The fund is allotted to individual researchers by peer review of their applications for research projects.

The origin of the Grants-in-Aid for Scientific Research subsidy goes back to 1918 . Successive budget

\footnotetext{
Received October 4, 2006; Revised December 25, 2006; Accepted January 17, 2007.

${ }^{1)}$ nisizawa@nii.ac.jp, ${ }^{2)}$ negishi@nii.ac.jp, ${ }^{3)}$ shibayama@nii.ac.jp,

4)yuan@nii.ac.jp, ${ }^{5)}$ nomura@u.dendai.ac.jp, ${ }^{6}$ maedam@iis.u-tokyo.ac.jp. DOI: $10.2201 / \mathrm{NiiPi} .2007 .4 .7$
}

increases led to it funds exceeding 1 billion yen in fiscal year (FY) 1955, even after the negative influence of the Second World War was accounted for. In FY 1965, the three related budgets were combined into the present day "Grants-in-Aid for Scientific Research". The twostep examination began in FY 1968. According to both the report of the Science Council in 1992 and the science and technological Basic Law of 1995, the budget exceeded 100 billion yen in FY 1996. Table 1 lists budgets and their growth rate from FY 1985 to 2005. [1]

\subsection{System improvement}

The system of Grants-in-Aid for Scientific Research (Grants-in-Aid) must continuously improve if it is to meet the needs of society and strengthen the research base of our country. The Council for Science and Tech- 
Table 1 Budget and growth rate from 1985 to 2005 FY [1].

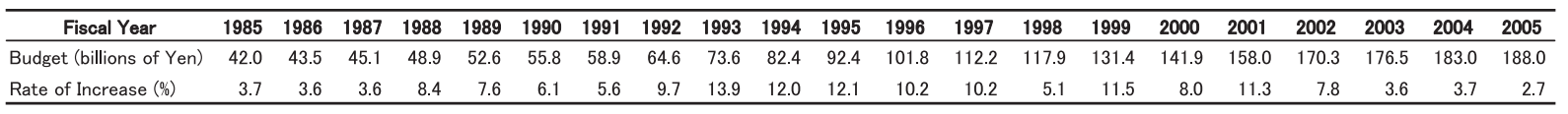

Table 2 Changes to the system of Grants-in-Aid after FY 1994.

\begin{tabular}{|c|c|}
\hline Year & System changes \\
\hline \multirow[t]{2}{*}{ FY1994: } & $\begin{array}{l}\text { (1) New Scientific Research ((A) (B) (C))* categories were established, and the former Developmental Scientific Research, Scientific } \\
\text { Research (A) and Scientific Research (B)(C) categories were integrated. }\end{array}$ \\
\hline & (2) Exploratory Research was established as a research category. \\
\hline FY1998: & The system for Scientific Research in Priority Areas (A) and (B) were improved. \\
\hline FY1999: & The International Scientific Research category was integrated into the Scientific Research category. \\
\hline FY2000: & The Scientific Research in Priority Areas (C) category was established for effective promotion for area as bioscience. \\
\hline \multirow[t]{2}{*}{ FY2001: } & (1) Scientific Research (S) category was established. \\
\hline & (2) Creative Scientific Research category was established as substitutes for the Grant-in-Aid for New Program. \\
\hline \multirow[t]{3}{*}{ FY2002: } & (1) Scientific Research in Priority Areas (A) (B) (C) categories were integrated into the Scientific Research in Priority Areas category. \\
\hline & $\begin{array}{l}\text { (2) The Grant-in-Aid for Young Scientists (A) and (B) categories were established as substitutes for the Encouragement of Young } \\
\text { Scientists (A) category. }\end{array}$ \\
\hline & (3) Specially Promoted Research (COE) category was established. \\
\hline FY2003: & A major change was made to the field classfication for the application. \\
\hline
\end{tabular}

nology of MEXT has attempted to revise the Grants-inAid system. Table 2 shows the changes that were made after FY 1994.

In FY 1999, some functions of the Grants-in-Aid program were transferred from former Monbusho (now MEXT) to the Japan Society for the Promotion of Science (JSPS). Tables 3 (a) and (b) list the research categories and their descriptions for FY 2004. The history and changes to the Grants-in-Aid system are detailed in the commentary of the Grants-in-Aid for Scientific Research. [2]

\section{Research activity based on Grants- in-Aid}

The number of Grants-in-Aid awards can be thought to be equivalent to the number of Research Active Staff (RAS) of a British university, because academic researchers individually apply for Grants-in-Aid without mentioning their organizations. Therefore, we consider a Japanese university in which a large number of researchers are awarded Grants-in-Aid to be an organization that has many active researchers, in the same sense as "RAS". The number of grant-holding researchers by field can be thought of as showing the degree of research activity in a particular field in that university.

A similar subsidy system to the one described above was established with the Grants-in-Aid in 1968. The field classification under which the researchers apply for awards has been continuously revised in accordance with the trends of the various research fields. Notably though, the classification for the Grants-in-Aid application has changed a great deal since FY 2003, in response to the reply of the Council for Science and Technology of MEXT. [4] Therefore, it seems to be important to compare data before the change in the system (FY 1998-2002) and data after the change (FY 2003) in order to check the effectiveness of the current Grantsin-Aid system.

\subsection{Databases of Grants-in-Aid for Scientific Research}

The official handbook [1] published each October by MEXT describes research subjects, budgets, etc., of Grants-in-Aid recipients. The National Institute of Informatics (NII) provides the "KAKEN" database (a service for disclosing the deliverables of grants-in-aid for scientific research) [5] as part of its "GiNii" platform.

We analyzed KAKEN database entries from FY 1998 to FY 2002 and in FY 2003.

We paid attention to the two points below when we looked at the number of subjects as a measure of research activity at a university.

(1) The applicant of the research subject is an individual or representative of a research group. The researchers do not have to be in the research organization that the research representative belongs to.

(2) There is a tendency for a researcher who belongs to 
Table 3

(a) Research categories and descriptions of Grants-in-Aid allocated by JSPS in FY 2004 Reprint from the JSPS web page [3].

\begin{tabular}{|c|c|c|}
\hline \multicolumn{3}{|r|}{ Description } \\
\hline \multicolumn{2}{|l|}{ Scientific Research } & Aid for Research \\
\hline \multirow[t]{2}{*}{ Scientific Research } & (S) & $\begin{array}{l}\text { Creative and leading-edge research conducted by university researchers individually or in small groups } \\
\text { Duration: } 5 \text { years } \\
\text { Grant: } 50-100 \text { million yen per project }\end{array}$ \\
\hline & $\begin{array}{l}\text { (A) } \\
\text { (B) } \\
\text { (C) }\end{array}$ & $\begin{array}{l}\text { Creative research conducted by university researchers individually or in groups } \\
\text { Duration: } 2 \text { to } 4 \text { years, or } 1 \text { year for research planning } \\
\text { Category A: } 20-50 \text { million yen per project } \\
\text { Category B: } 5-20 \text { million yen per project } \\
\text { Category C: Up to } 5 \text { million yen per project }\end{array}$ \\
\hline \multicolumn{2}{|c|}{ Encouragement of Scientists } & $\begin{array}{l}\text { Research carried out by individual pre-school, elementary, secondary school or teachers or by an } \\
\text { individual citizen } \\
\text { Duration: } 1 \text { year } \\
\text { Grant: Up to } 0.3 \text { million yen per project }\end{array}$ \\
\hline \multicolumn{3}{|c|}{ Publication of Scientific Research Results } \\
\hline \multicolumn{2}{|l|}{ Scientific Periodicals } & $\begin{array}{l}\text { Publication of academic journals periodically by academic societies or groups of cooperating academic } \\
\text { societies to promote international exchange }\end{array}$ \\
\hline \multicolumn{2}{|l|}{ Scientific Literature } & Publication of academic books to disseminate research results by individuals or groups of researchers \\
\hline \multicolumn{2}{|l|}{ Databases } & $\begin{array}{l}\text { Compilation of databases by individuals or groups of researchers that have already proved practical and } \\
\text { have the purpose of openly disseminating information through academic information systems, etc. }\end{array}$ \\
\hline \multicolumn{2}{|l|}{ Creative Scientific Research } & $\begin{array}{l}\text { Aimed at the further cultivation of fruits obtained from highly creative research conducted under the } \\
\text { Grants-in-Aid for Scientific Research and other funding programs } \\
\text { Duration: } 5 \text { years }\end{array}$ \\
\hline
\end{tabular}

(b) Research categories and descriptions of Grants-in-Aid allocated by MEXT in FY 2004 [3].

\begin{tabular}{|c|c|}
\hline Categories & Description \\
\hline Scientific Research & Aid for Research \\
\hline $\begin{array}{l}\text { Specially Promoted } \\
\text { Research }\end{array}$ & $\begin{array}{l}\text { Highly regarded research likely to bring outstanding results } \\
\text { Duration: } 3-5 \text { years }\end{array}$ \\
\hline $\begin{array}{l}\text { Scientific Research in } \\
\text { Priority Areas }\end{array}$ & $\begin{array}{l}\text { Specific areas that can elevate research in basic fields of science or that can contribute to the } \\
\text { development of Japan's economy and society } \\
\text { Duration: } 3-6 \text { years } \\
\text { Grant: approx. } 20-600 \text { million yen yearly per area }\end{array}$ \\
\hline \begin{tabular}{|l|l|} 
Exploratory Research & \\
& $\left({ }^{*}\right)$
\end{tabular} & $\begin{array}{l}\text { Uniquely original research using unexpectedly surprising ideas in an early stage of development } \\
\text { Duration: Up to } 3 \text { years } \\
\text { Grant: Up to } 5 \text { million yen per project }\end{array}$ \\
\hline 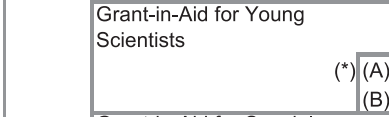 & $\begin{array}{l}\text { Research carried out by individual researchers of up to age } 37 \\
\text { Duration: } 2-3 \text { years } \\
\text { Category A: } 5-30 \text { million yen per project } \\
\text { Category B: Up to } 5 \text { million yen per project }\end{array}$ \\
\hline $\begin{array}{l}\text { Grant-in-Aid for Special } \\
\text { Purposes }\end{array}$ & Support for urgent or important research projects \\
\hline \multicolumn{2}{|l|}{ Publication of Scientific Research Results } \\
\hline $\begin{array}{l}\text { Announcement of Publication of } \\
\text { Scientific Research Results }\end{array}$ & Publication of research results with high academic evaluation and highly valuable academic information \\
\hline Specially Designated Research Promotio & $\begin{array}{l}\text { Support for research of a strong academic or societal character conducted by designated private } \\
\text { research institutes }\end{array}$ \\
\hline Grant-in-Aid for JSPS Fellows & $\begin{array}{l}\text { Support for research conducted by JSPS fellows (including foreign fellows) } \\
\text { Duration: Up to } 3 \text { years }\end{array}$ \\
\hline
\end{tabular}

a large organization, especially a large university to become a research representative because the Grants-inAid application needs extensive accounting, documentation, preparations, etc.

\subsection{Situation from FY 1998 through 2002 \\ 2.2.1 Outline of general analysis}

Grants-in-Aid for Scientific Research no doubt supported the basic research of universities in postwar.

The budget began to be distributed preponderantly as a competitive research fund to promote science and technology with priority on graduate schools in 1991. Table 1 shows the Grants-in-Aid yearly budget and its rate of change. Although the budget has increased, the rate seems to have slowed since FY 2003. The top class of the classification table for the applications of Grantsin-Aid (Scientific Research (S), (A), (B), (C), Grantsin-Aid for Exploratory Research, and Grants-in-Aid for Young Scientists (A), (B)) consist of the seven traditional fields of literature (classified as Arts/Humanities in this section), law, economics, science, engineering, agriculture and medicine and Interdisciplinary studies and General studies. Table 4 shows the number of research subjects, and corresponding budget allotments from FY 1988 to FY 2002 by grant type and by research area. Fig. 1 shows the percentage of grants based on the number of awards as broken down by research area from FY 1998 to FY 2002. This figure shows that the field of medicine accounts for the largest part of the fund. 


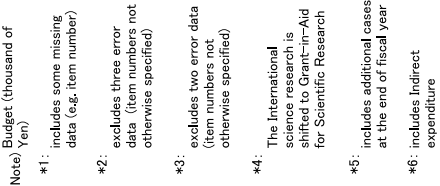

定

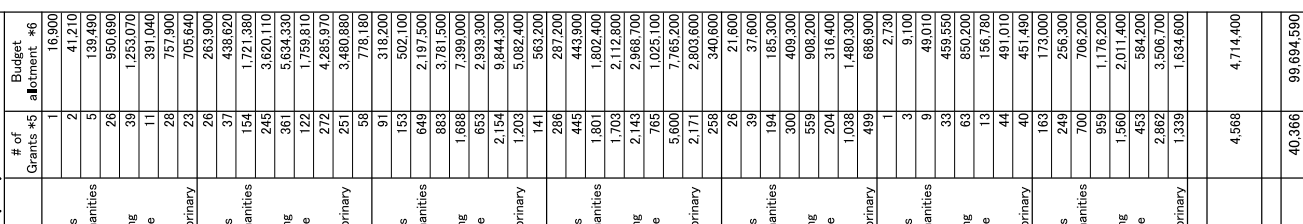

ิิ

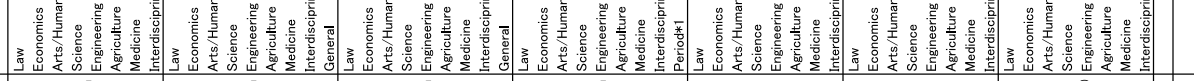

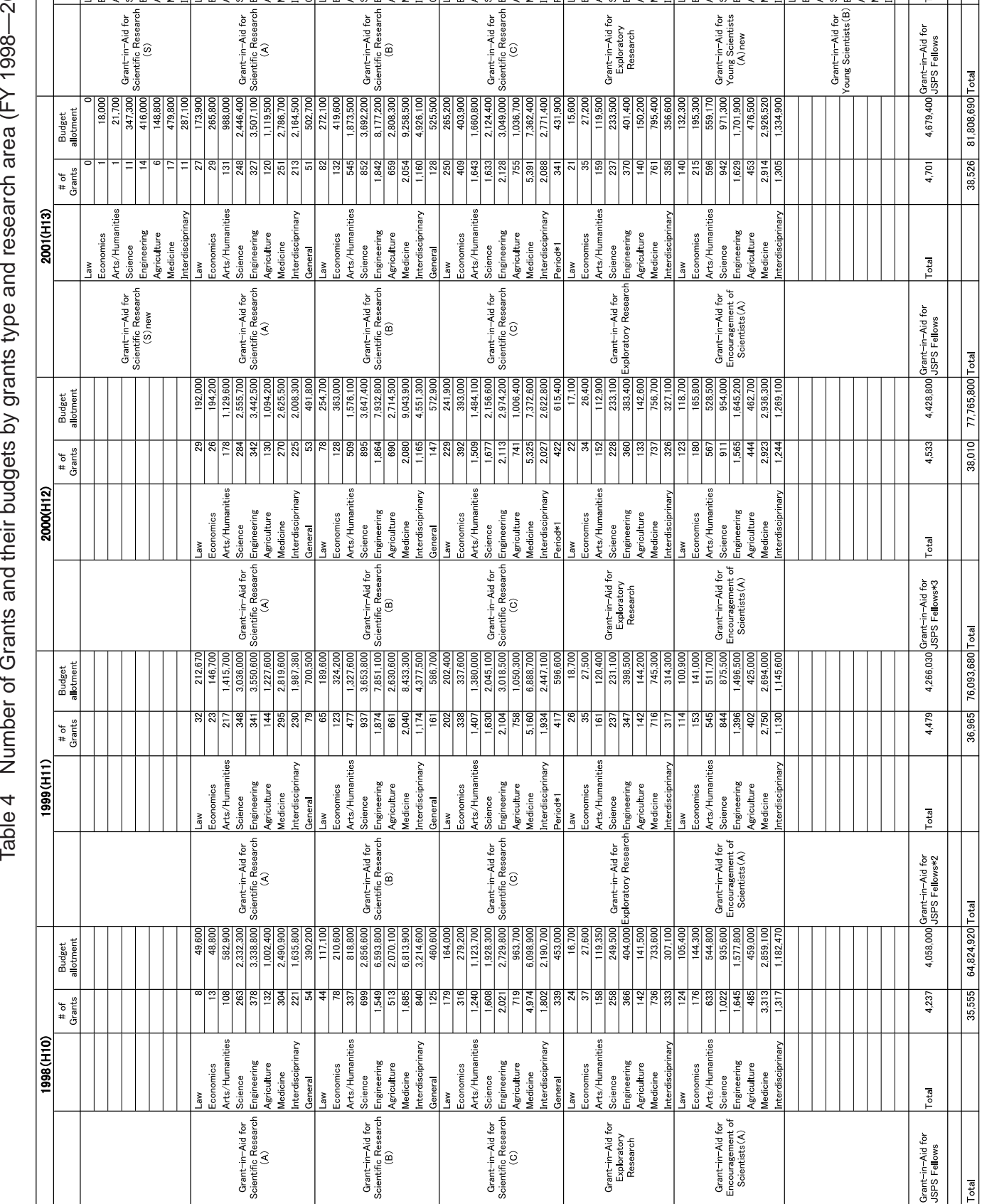




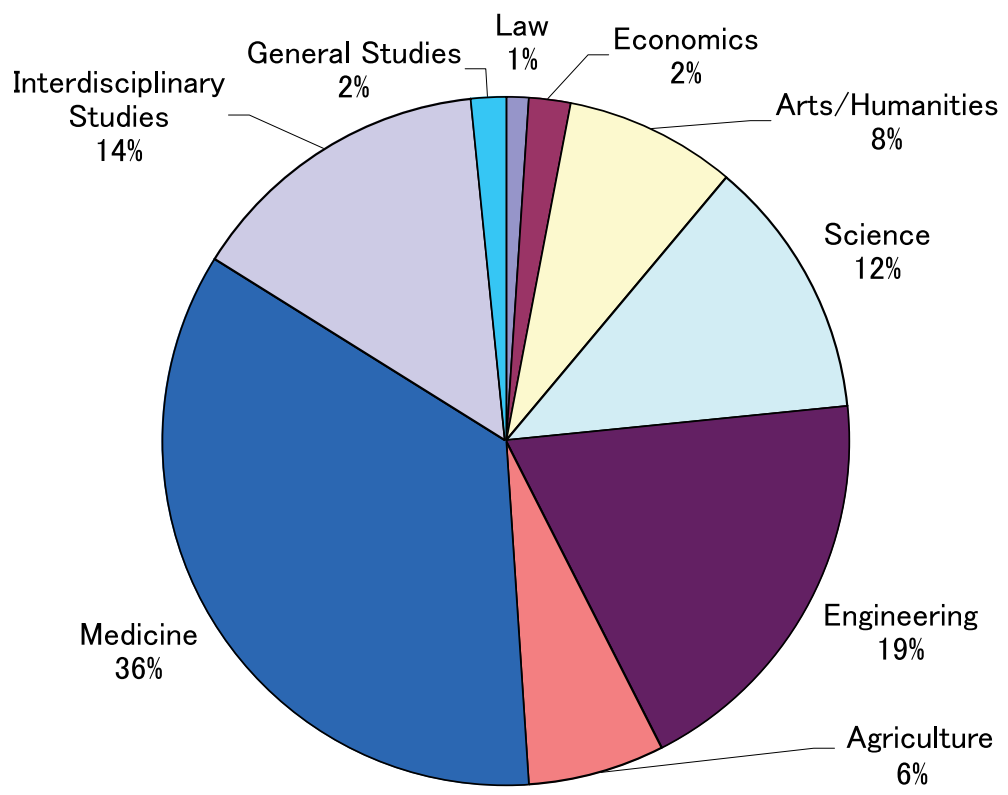

Fig. 1 Percentage of grants broken down by research area(FY 1998-2002).

\subsubsection{Analysis of individual research areas, JSPS fel-} lows and large-scale and huge research projects

Next, we show the results of individually analyzing six composite domains of (1) law, economics, arts and humanities and education, (2) science, engineering and agriculture, (3) medical science, dentistry, pharmacy and nursing, (4) interdisciplinary studies, (5) Grantsin-Aid for JSPS Fellows and (6) Large-scale Project Funds. The tables and figures of the analysis show that national and large private universities play the most important role, but some smaller universities also take large.

Although the details can't be discussed for reason of space, the reader can see that the number of Grantsin-Aid awarded per field reflects the degree of research activity in the fields that the university especially focuses on. The detailed breakdowns are available in the technical report of the National Institute of Informatics (NII). [6]-[16]

The research field classification table that includes the top and second level research areas for application in FY 2002 is shown in Appendix 1.

(1) Law, Economics, Arts/Humanities, and Education

Table 5 shows the top 50 organizations that grantholding researchers belong to. The first columns of the table show breakdowns for the area composed of law, economics, arts/humanities. The other columns list data individually for law, economics, arts/humanities, and the area composed of psychology, sociology, edu- cation, and cultural anthropology subfields belonging to arts/humanities classification. The last area is selected in order to measure an activity of faculty of education in the Japanese universities. On the whole, the table shows that the large national universities (the former imperial universities under the old system of higher education) are generally ranked higher in every field, but certain private universities are also well represented. The research characteristics of universities and institutes are clearly revealed in the categories of law, economics, arts/humanities, and education. Figs. 2 and 3 show the budget and the percentages of number of subjects included in arts/humanities and social sciences (law and economics).

\section{(2) Science, Engineering and Agriculture}

Science and engineering in Japan have been extensively supported by this system, and the importance of the system to these areas is increasing. This report clarifies the roles of individual universities in each research field of science, engineering, and agriculture.

Table 6 shows the top 50 organizations that grantholding researchers belong to. The table lists totals for science, engineering, and agriculture, as well as science and engineering together.

On the whole, the large national universities that were imperial universities under the old system of higher education are generally ranked higher in every field, but some private universities are well represented. The research characteristics of universities and institutes are clearly revealed in the science, engineering, 


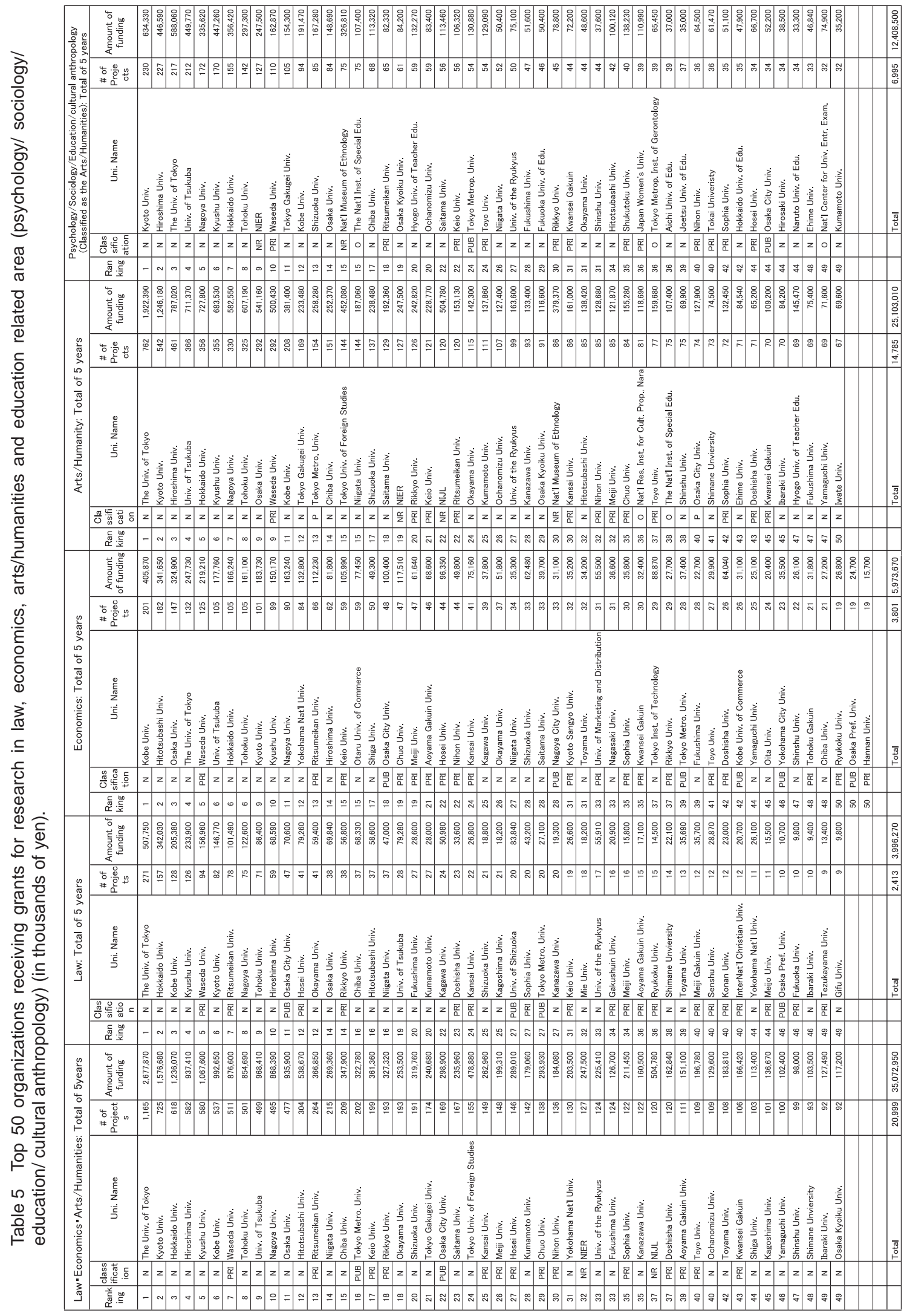




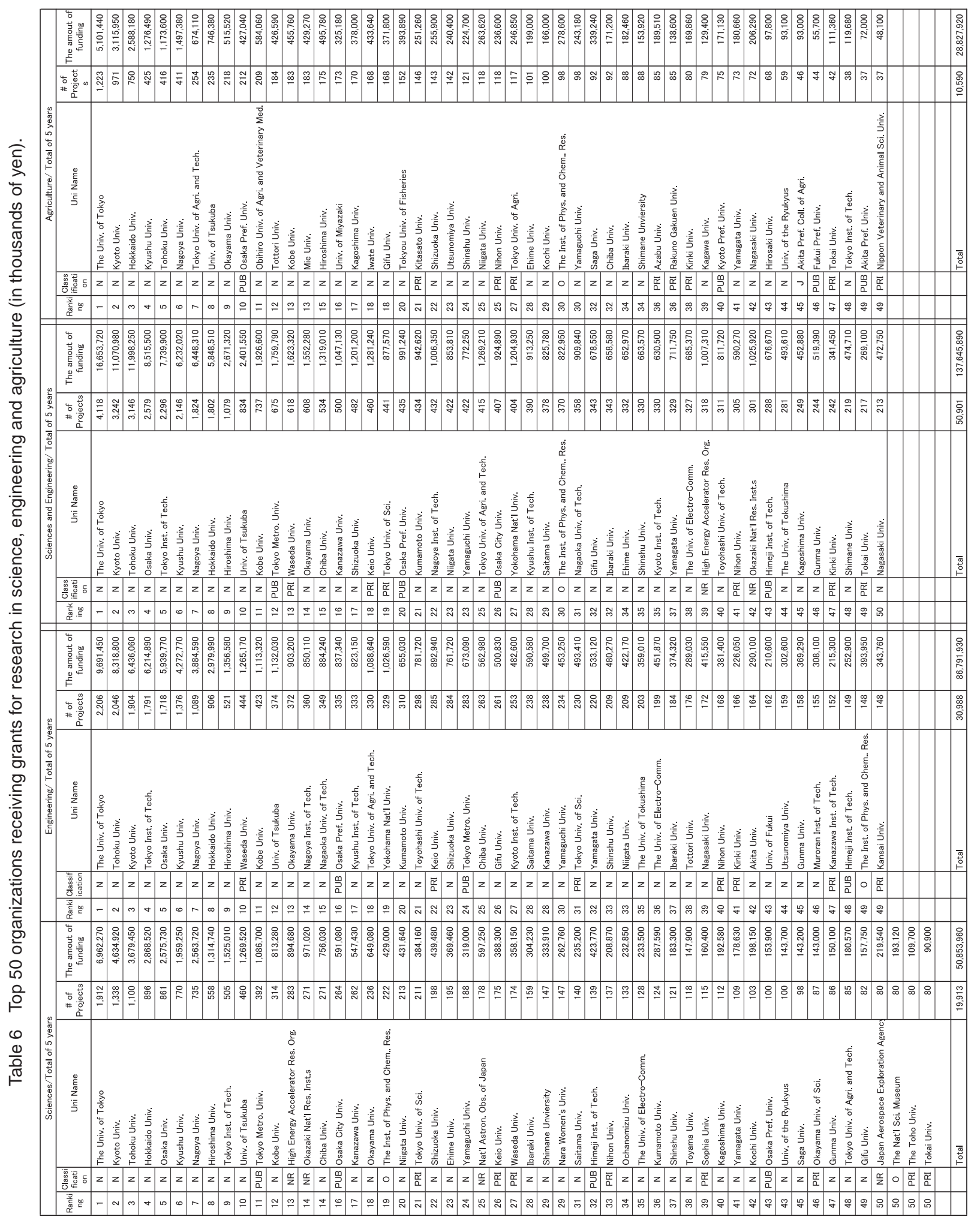




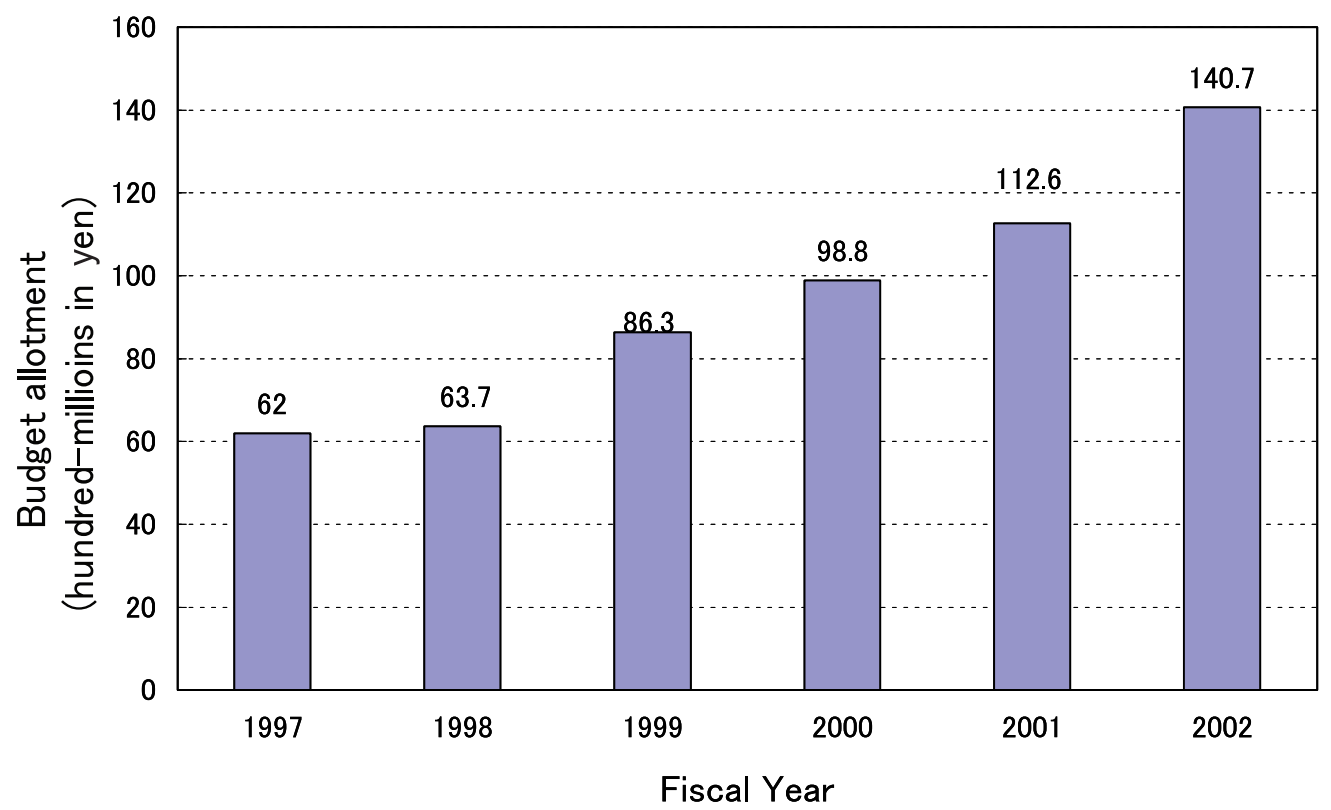

Fig. 2 Budget allotment to arts/humanities and social sciences.

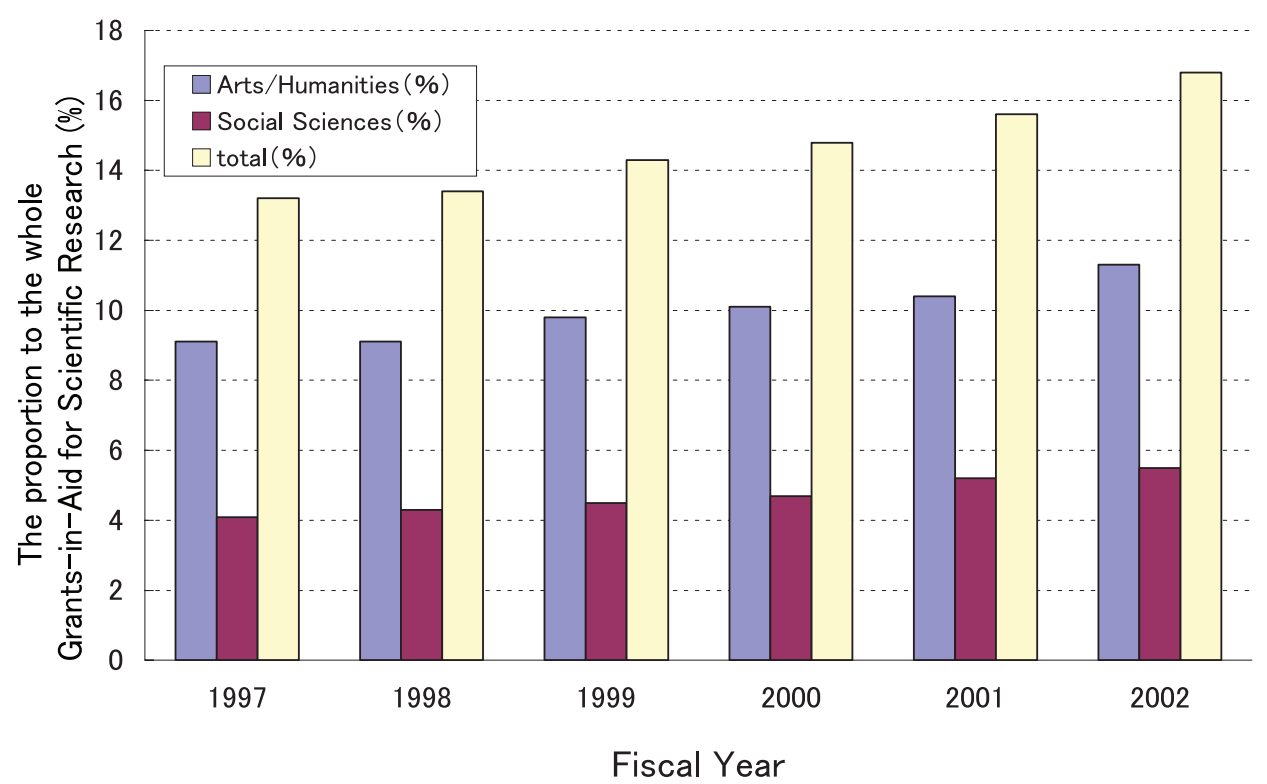

Fig. 3 Proportion of number of subjects included in arts/humanities and social sciences to the whole.

and agriculture categories.

Fig. 4 shows changes in the number of subjects funded in science, engineering, and agriculture over FY 1998-2002. Each area has shown a little growth in number of subjects funded during this period.

(3) Medical Science, Dentistry, Pharmacy and Nursing These research fields develop medical treatments and promote the welfare of the Japanese people. Their importance is thus reflected in the large number of awards of Grants-in-Aid for medical science, dentistry, pharmacy and nursing. In fact, their share is $34 \%$ of all funded research subjects. The large share is especially evident in comparison with the shares of science, engineering, and agriculture. Note that the detailed clas- 


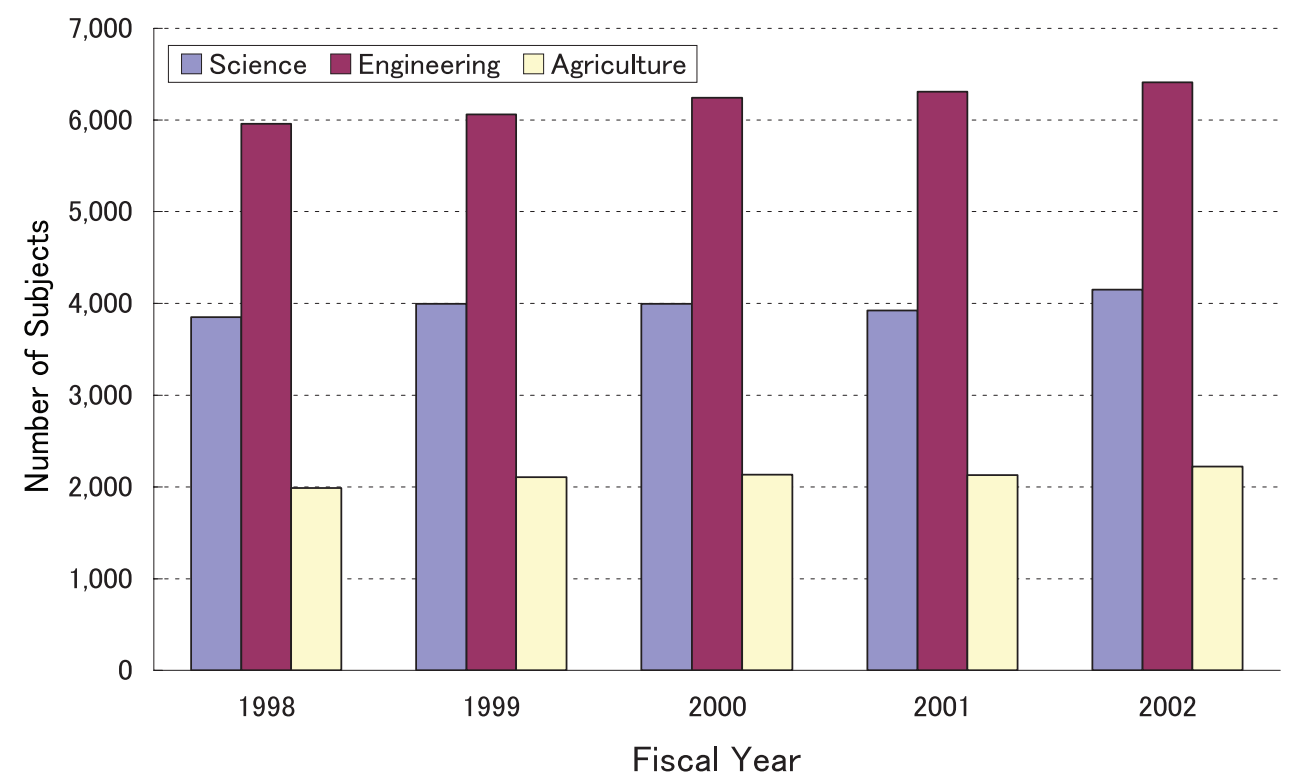

Fig. 4 Changes in number of subjects included in science, engineering and agriculture classifications.

sification code of MEXT of the medical domain consists of nine subfields: physiology, pathology, social medicine, internal medicine, surgery, dentistry, pharmacy, medicine in general, and nursing science. Here, we reclassified these nine subfields into five fields: (A) basic medicine [physiology and pathology], (B) clinical medicine [internal medicine, surgery, and medicine in general], (C) dentistry, (D) pharmacy and (E) social medicine and nursing, after considering the present situations of medical departments in Japanese universities.

Fig. 5 shows changes in the number of subjects in the five fields over FY 1998-2002. Each field has had a little growth during this period. Fig. 6 also shows changes in the amount of funding for each field.

Table 7 shows the top 50 organizations that researchers belong to. The table shows the breakdown for the overall research field of medicine and for individual areas of physiology, pathology, internal medicine, surgery, and medicine in general ((A) plus (B)); dentistry (C), pharmacy (D); and social medicine and nursing $(\mathrm{E})$.

On the whole, although the former imperial universities were generally ranked higher in every field, the general aspect of this ranking is completely different from those of the previous two rankings. Many private and medical universities are in the middle in the top 50. The research characteristics of universities and institutes are clearly revealed in the categorization of medical science, dentistry, pharmacy, and nursing.

\section{(4) Interdisciplinary Studies}

This area includes interdisciplinary studies, general studies, and new research fields that are difficult to include in the traditional disciplines. The ranking of these fields indicates the research activities of interdisciplinary and new fields.

Fig. 7 shows the changes in the number of subjects funded in interdisciplinary and general areas, and projects with limited periods. Fig. 8 shows the oportion of funded subjects broken down by individual interdisciplinary area of study.

The national and large private universities are well represented, as are some smaller universities.

Table 8 shows the top 50 and 30 organizations to which funded researchers belong to in the interdisciplinary and general area classification.

The research characteristics of universities and institutes are clearly revealed in the individual research areas.

\section{(5) JSPS Fellows}

The Japan Society for the Promotion of Science (JSPS) has a special fellowship system to educate young researchers. The Grants-in-Aid are allotted to JSPS fellows to encourage research. Therefore, the number of funded subjects corresponds to the number of young researchers at each university and also to the degree that each university educates young researchers.

Fig. 9 shows the proportion of number of funded subjects of Grants-in-Aid for JSPS fellows broken down by research field in FY 2002. 


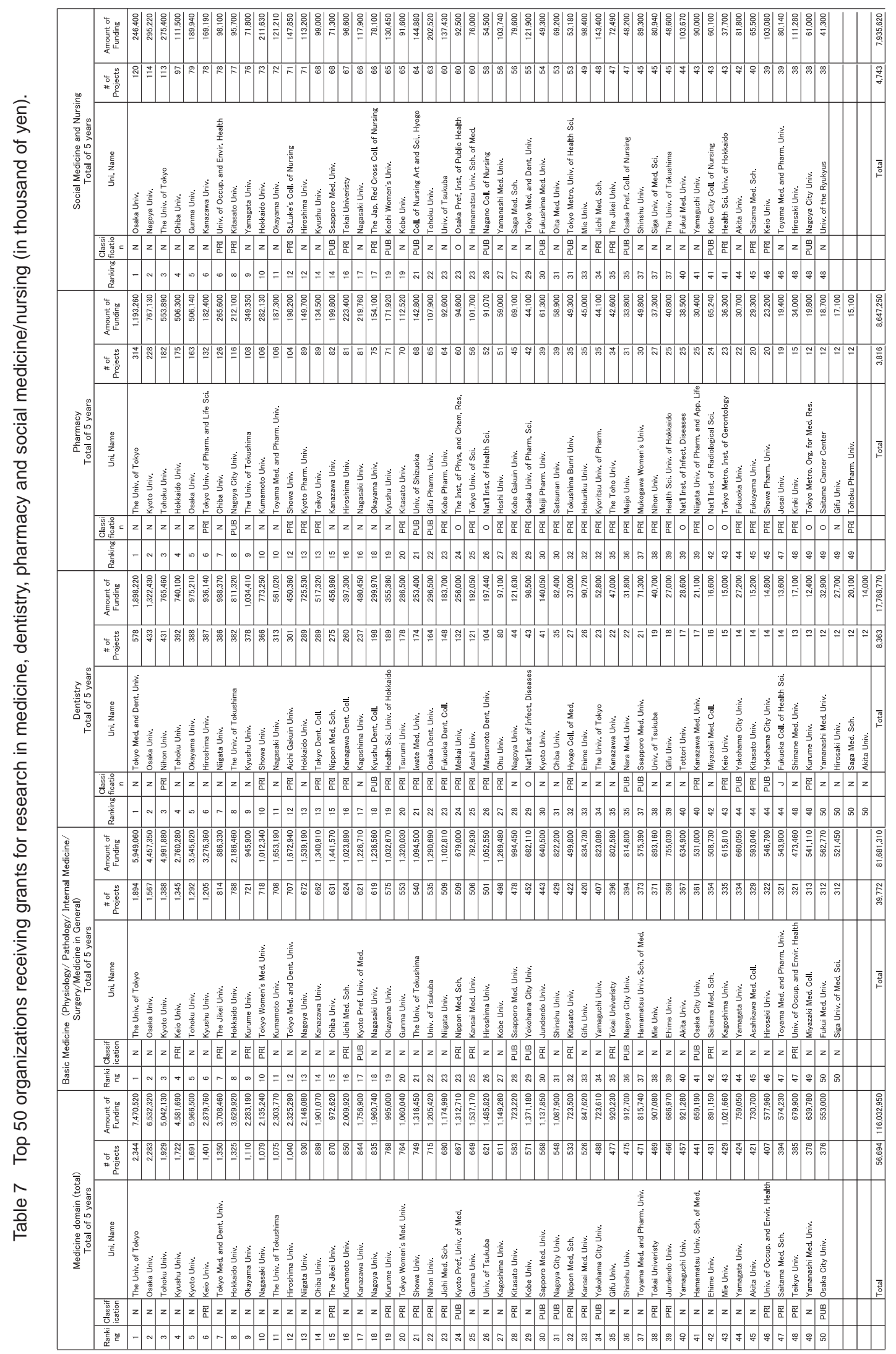




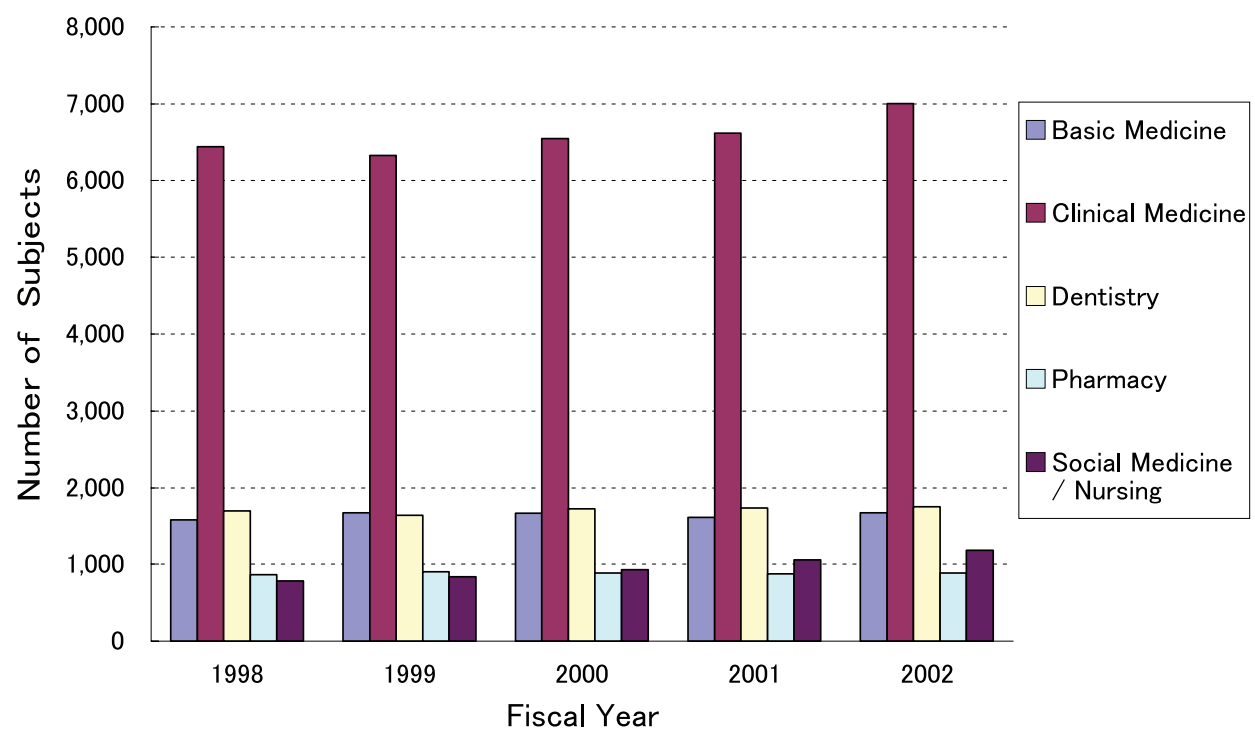

Fig. 5 Changes in number of subjects in the medicine classification.

(Basic Medicine includes physiology and pathology. Clinical Medicine includes internal medicine, surgery, and medicine in general).

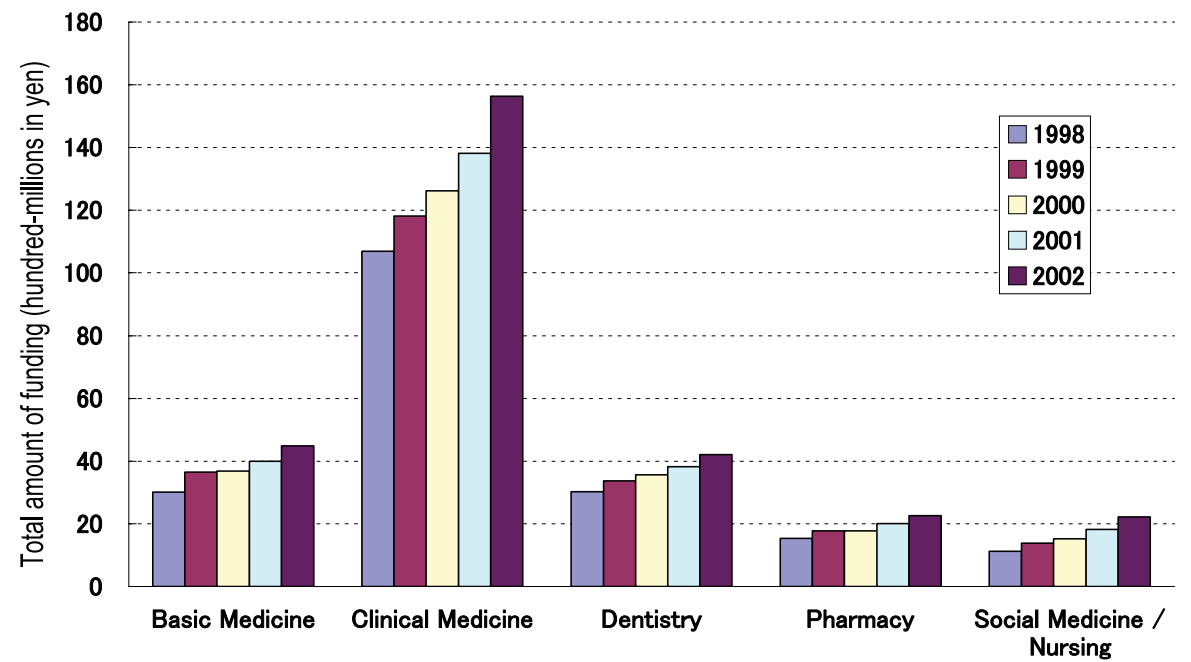

Fig. 6 Changes in funding for each area in medicine classification.

(Basic Medicine includes physiology and pathology. Clinical Medicine includes internal medicine, surgery, and medicine in general).

Fig. 10 shows the number of funded subjects for JSPS fellows per organization. This figure shows that the University of Tokyo has the predominant number of funded subjects, and Kyoto University is has the second largest. There is a large difference between the top group consisting of the former imperial universities and the Tokyo Institute of Technology and lower ranked organizations starting with Tsukuba University, Waseda
University and Keio University. This figure shows the importance of the old imperial universities in training the researchers of our country.

\section{(6) Large-scale Project Funds}

Large-scale projects are funded with large grants called Scientific Research on Priority Areas and University and Society Collaboration, and huge grants 


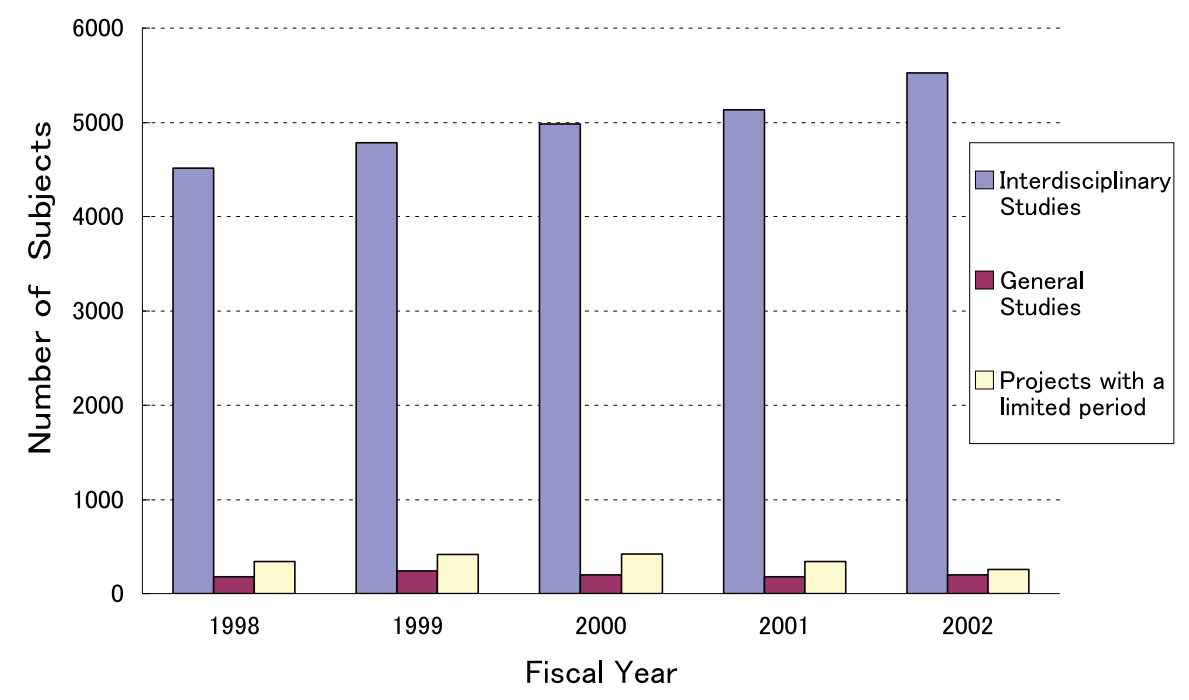

Fig. 7 Changes in number of subjects included in interdisciplinary studies / general studies / projects with a limited period classification.

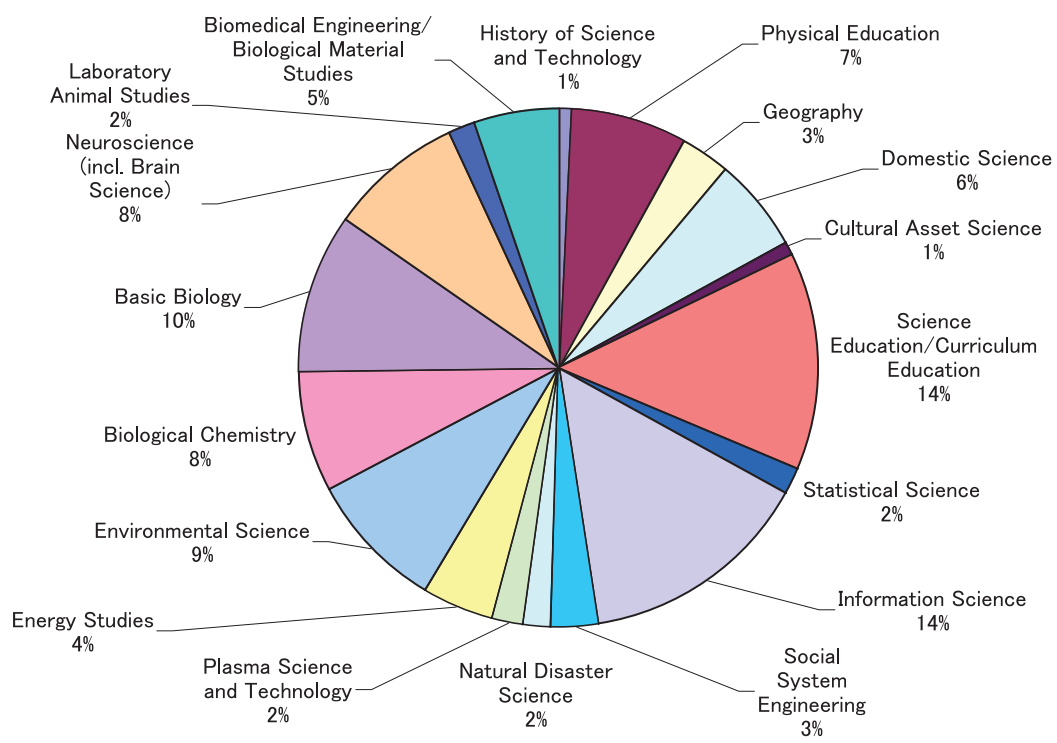

Fig. 8 Percentage of subjects in the interdisciplinary studies classification.

called Specially Promoted Research, Special Purpose Research, Creative Scientific Research (former Grantsin-Aid for New Program), and Center of Excellence (COE) Research. Since the project leaders of these research projects mostly belong to large national universities, many special research grants are allotted to the researchers in large national universities. In addition, large private universities are well represented, and some smaller universities are also highly ranked.

Fig. 11 shows the proportion of total budget broken down according to the above-stated research categories for FY 2001.

In the case of Scientific Research on Priority Areas, as shown in Fig. 12, large national universities such as the University of Tokyo and Kyoto University occupy the top ranks. However, certain research institutes or graduate school universities, for example, Okazaki National Research Institutes, the Institute of Physical and Chemical Research and Nara Institute of Science and Technology are ranked higher in this category than they 


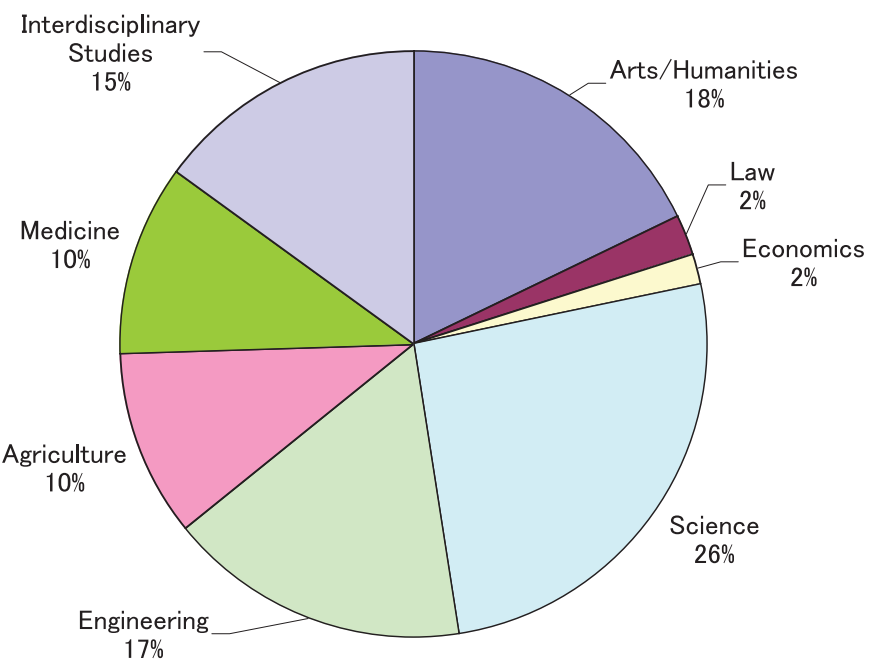

Fig. 9 Proportion of number of funded subjects for JSPS fellows broken down by research field (FY 2002).

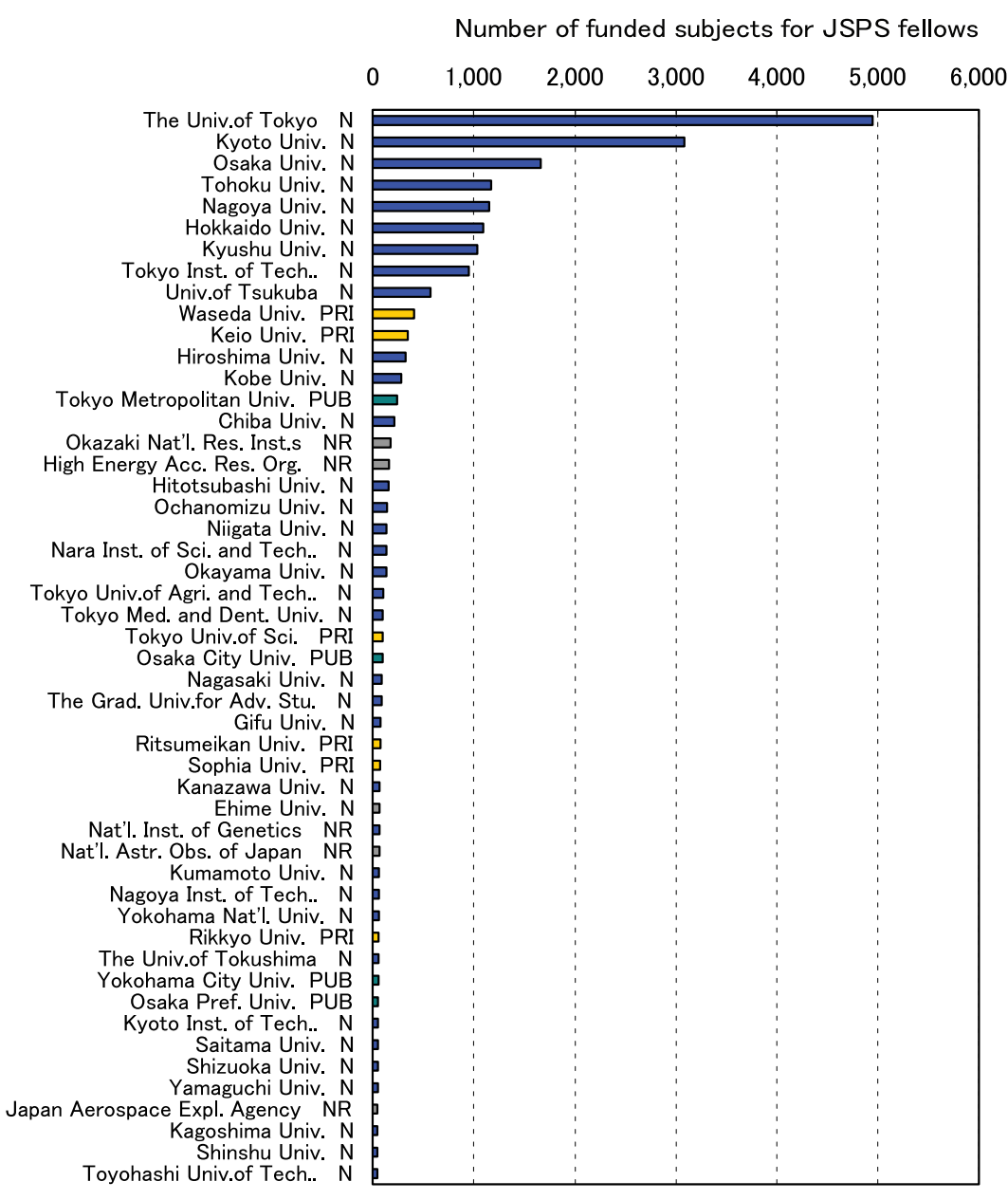

Fig. 10 Number of funded subjects for JSPS fellows by organization. 
Table 8 Top 50 (30) organizations receiving grants for interdisciplinary and general studies.

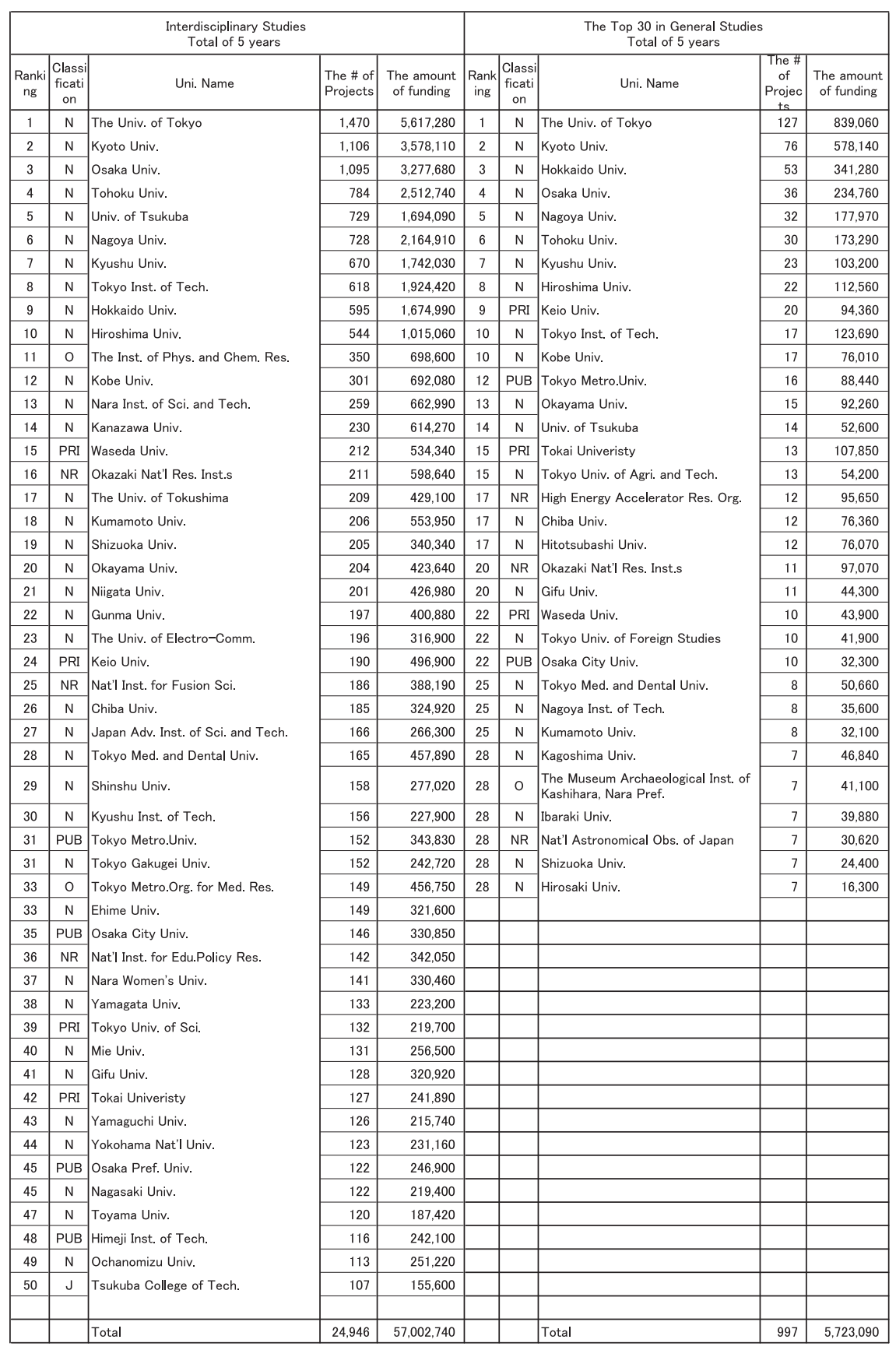

are in the general category of Scientific Research of Grants-in-Aid.

The Specially Promoted Research is for research regarded as likely to bring outstanding results and high evaluations at the international level. The funds for a research subject of this category are usually about 500 million yen. Fig. 13 shows the number of awarded subjects for each organization from FY 1998 to 2002. The
University of Tokyo and Kyoto University have especially large numbers of funded subjects. In contrast, universities below the tenth rank are hardly represented. The number of subjects funded in this category is not proportional to the scale of the organization. It is obvious that the subjects in this category are awarded according to the individual researcher's achievement. 


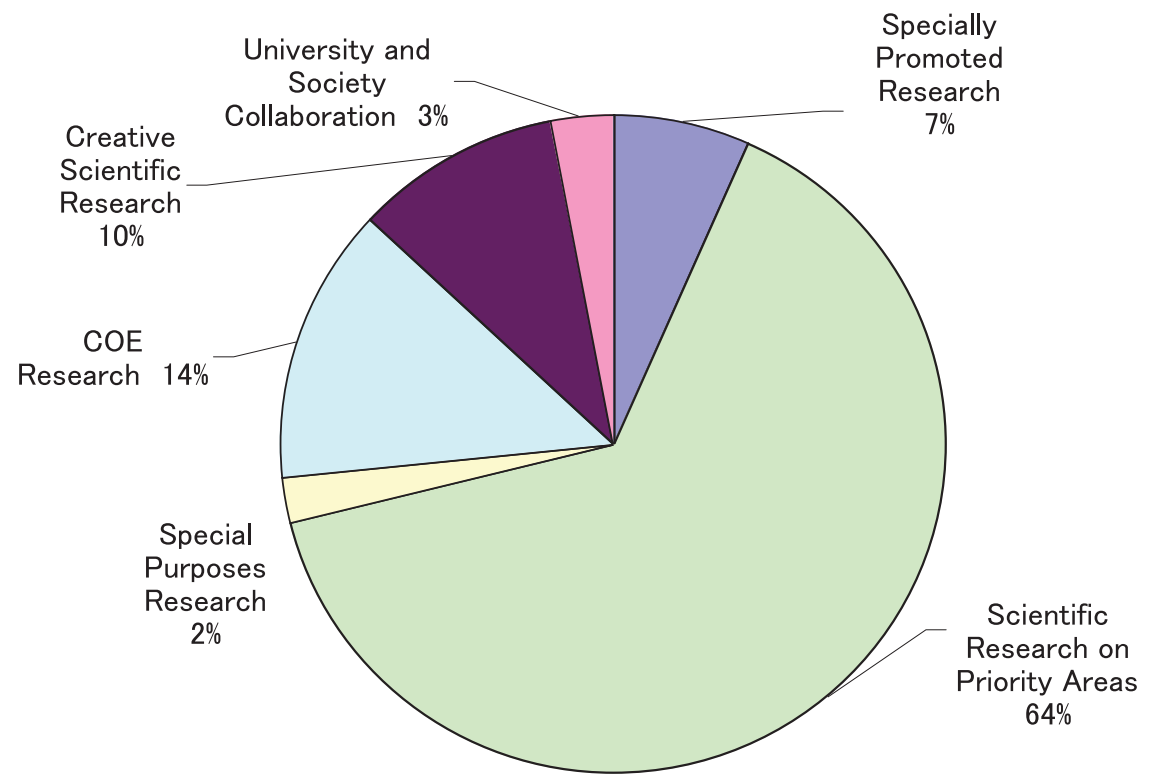

Fig. 11 Proportion of budget categories funded as Large-scale Projects (FY2001).

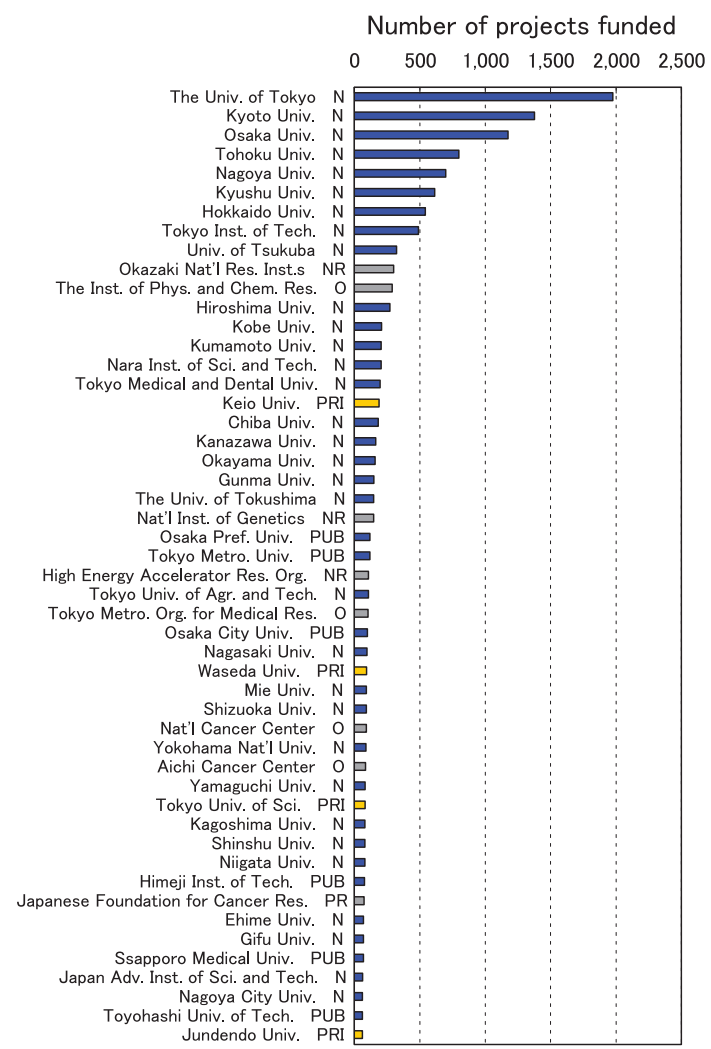

Fig. 12 Number of projects funded under Scientific Research on Priority Areas by organization (FY 1998-2002).

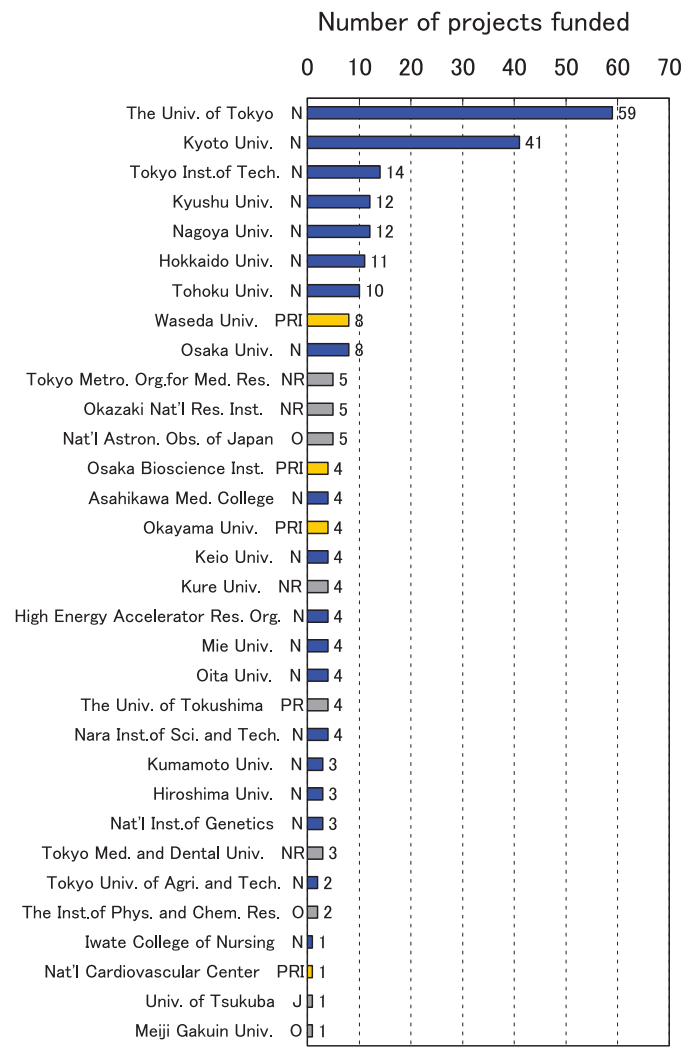

Fig. 13 Number of projects funded as Specially Promoted Research by organization (FY 1998-2002). 


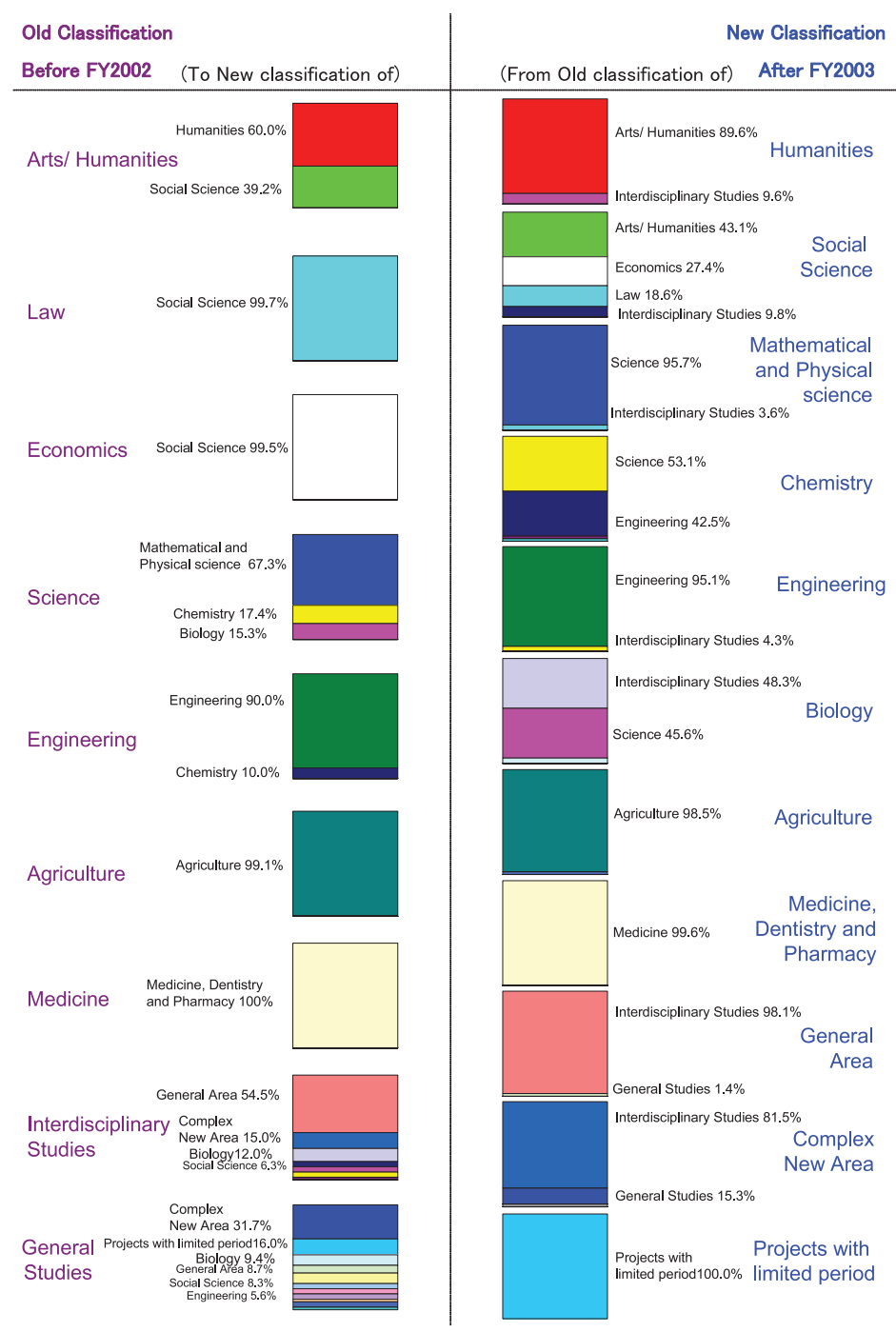

Fig. 14 Before and after the field classification change.

\subsection{Situation in FY 2003 (after modification to field classification)}

\subsubsection{Outline of general analysis}

According to development of the science and technology, the research field codes of Grants-in-Aid for Scientific Research have been revised every five years. In middle of FY 2002, a large modification was undertaken in the research field codes in response to the reply of the Council for Science and Technology [4] of MEXT. A new revised table of research field codes was used for the application for FY 2003 research projects.

The table was changed from nine areas, which consist of seven traditional fields (literature, law, economics, science, engineering, agriculture and medical science) and interdisciplinary and general areas to- gether, to four research areas of general / complex new areas, humanities and social science, science and engineering, and biosciences. The sub-areas increased from 243 to 278, meanwhile the grant categories and budget by category were left almost unchanged. The classification table for application in FY 2003 is shown in Appendix 2.

Using the database for FY 2003, the research projects that are designated a "continuation" from FY 2002 were extracted from the grant category (including Scientific Research, Grants-in-Aid for Young Scientists, and Exploratory Research) to which the application work fields are given. Fig. 14 shows the relationship between the situations before and after the field classification change based on number of "continuation" re- 


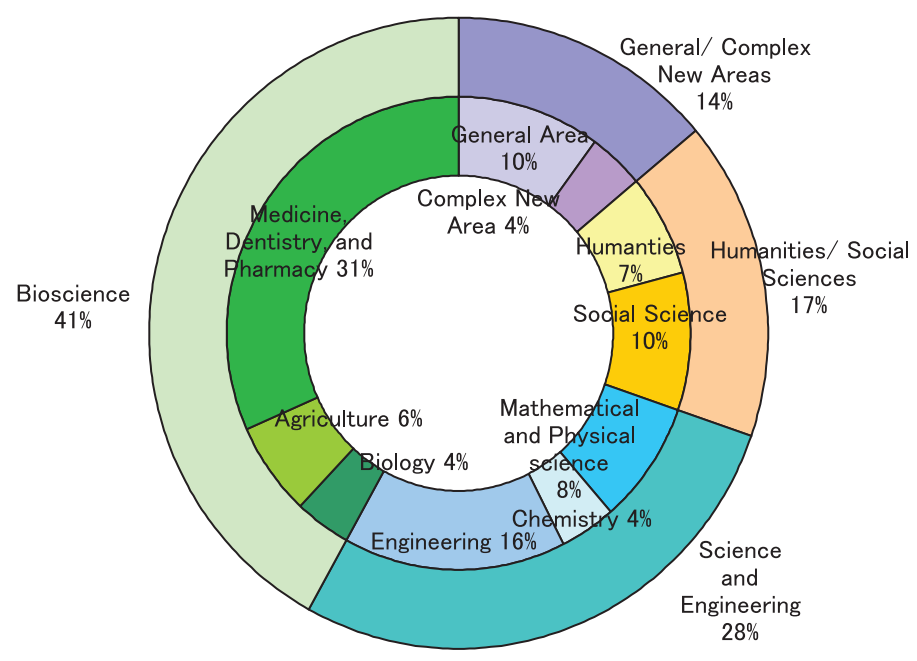

Fig. 15 Proportion of projects awarded in FY 2003 broken down by top class fields (outer) and specific area (inner).

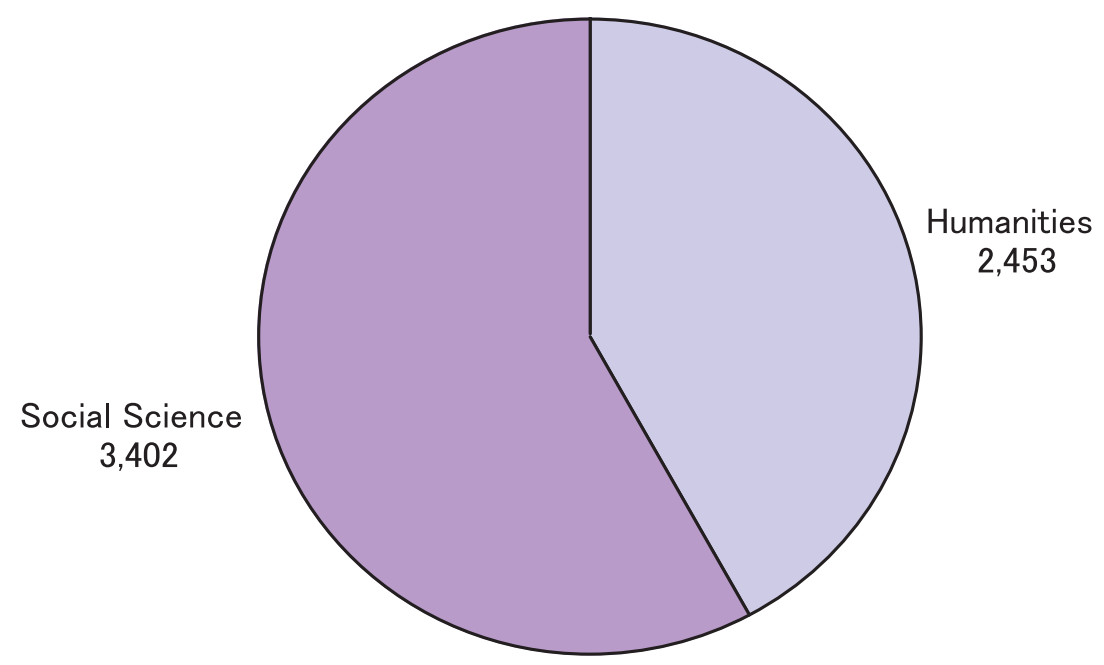

Fig. 16 Number of projects awarded in humanities/social sciences (2003 FY).

search projects. It shows the differences of the field classification in each area.

Fig. 15 shows the percentage of projects awarded in FY 2003 broken down by top class fields (outer) and specific area(inner).

\subsubsection{Analysis of individual research areas}

(1) Humanities and Social Sciences

In the humanities and social sciences, one of the major revisions was in the humanities classification. The fields of psychology and pedagogy (education) were shifted from the arts and humanities to the social sciences. Linguistics became a subfield in the humanities. Fig. 16 shows the number of funded projects broken down by subject in the humanities and social sciences in FY 2003.

\section{(2) Sciences and Engineering}

In science and engineering, one of the major revisions was in the sciences category. The classification "Biology" was changed to "Biosciences", "Chemistry" was identified as its own field, and "Applied Chemistry" and "Materials Science" became part of "Engineering". Fig. 17 shows the number of awarded projects broken down by field in science and engineering in FY 2003.

\section{(3) Biosciences}

Biosciences comprise biology, agriculture, medical 


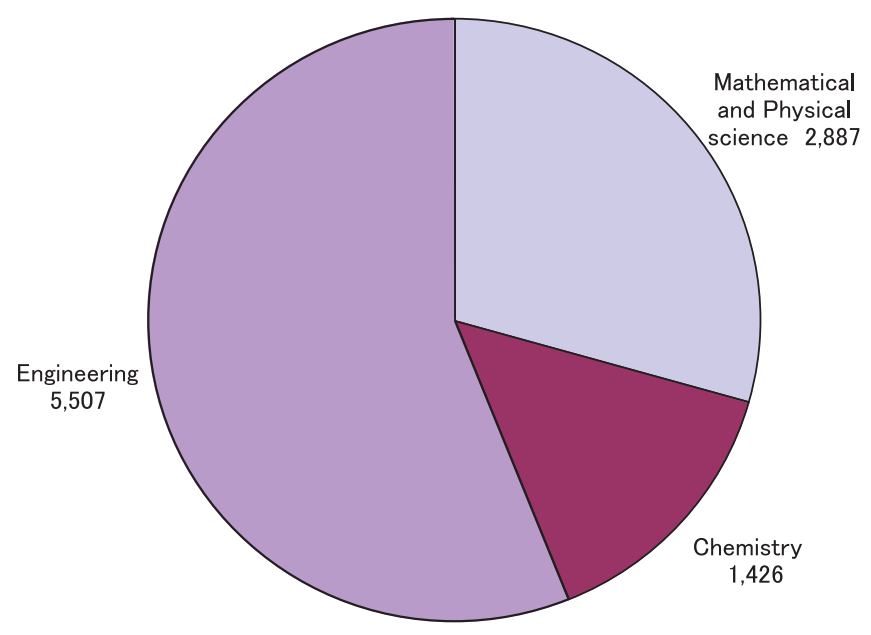

Fig. 17 Number of projects awarded in science and engineering (FY 2003).

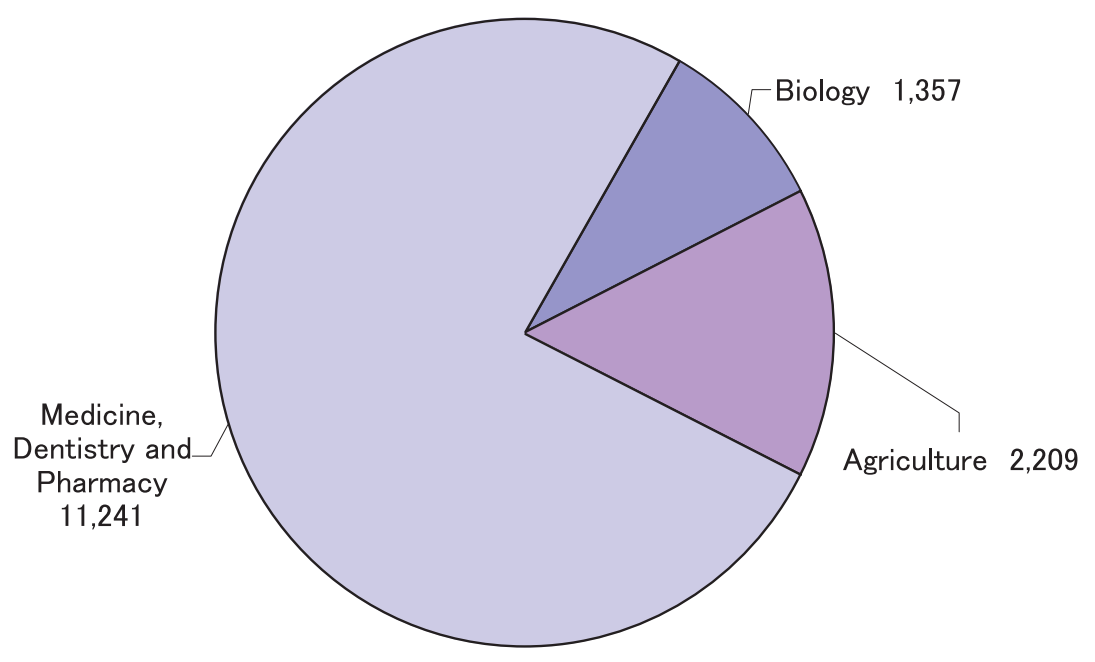

Fig. 18 Number of projects awarded in the Biosciences area (FY 2003).

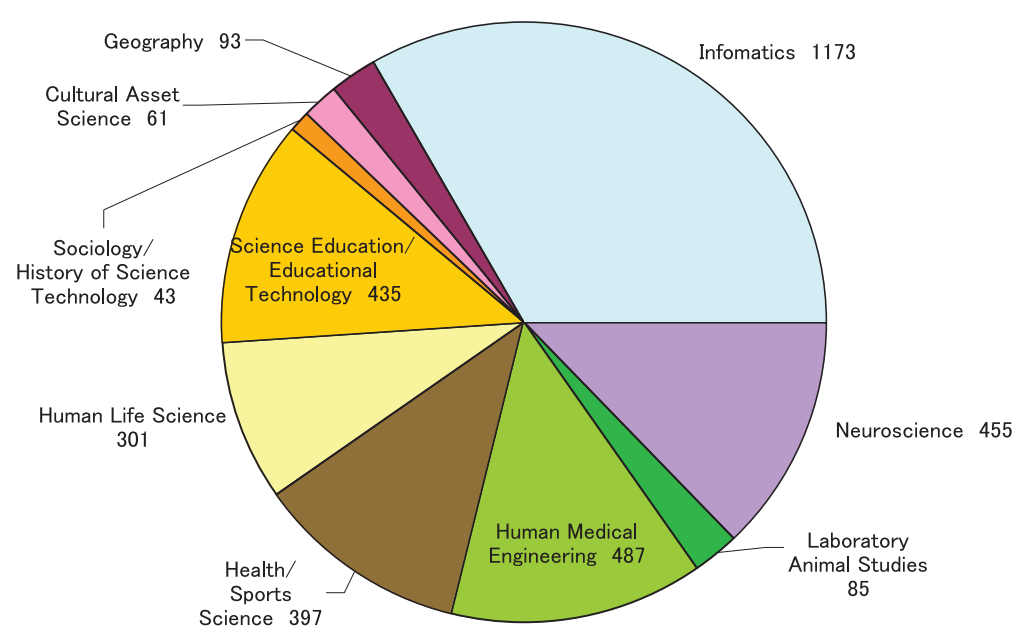

Fig. 19 Number of projects in the General area (FY 2003). 


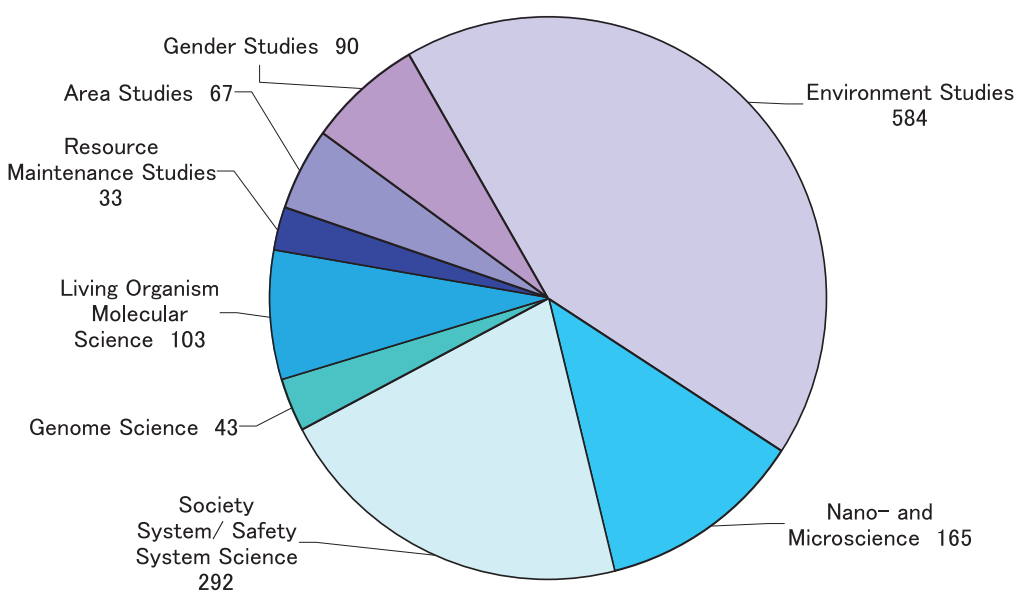

Fig. 20 Number of projects awarded in the Complex New areas (FY 2003).

science, dentistry, and pharmacy. The medical science category comprises basic medicine, internal medicine, and surgery. $31 \%$ of the total fund, which is the largest portion of the research budget, was allocated to the medical, dental, and pharmaceutical fields. Fig. 18 shows the number of projects awarded broken down by research field in the Biosciences area in FY 2003.

\section{(4) General and Complex New Areas}

The General and Complex New areas include subfields rearrangements of the previous Interdisciplinary Studies area. Figs. 19 and 20 show the breakdown of the General area and the Complex New research area. These areas include nano- and microsciences.

The total number of funded subjects in FY 2003 was tallied for each university and institute for new research fields and compared with the totals of 1998-2002 that were reported in the previous section and in NII Technical Reports. The results for the total number and amount of funds distributed by organization are also shown in the NII Technical Report. For more details, please refer to the NII Technical Report and related books. [6]-[18]

\section{References}

[1] Ministry of Education, Culture, Sports, Science and Technology (Gyosei ed.), The adoption and examination handbook of Grants-in-Aid for Scientific research, Gyosei, ISBN4-324-07203-5, 1998, 1999, 2000, 2001, 2002, 2003 (in Japanese).

[2] Hajime ENDO, Commentary of the Grants-in-Aid for Scientific Research, Gyosei, IDBN4-324-07702-9, 2005 (in Japanese).

[3] Japan Society for the Promotion of Science (JSPS), "Grants-in-Aid for Scientific Research": http://www.jsps.go.jp/english/e-grants/grants.html

[4] The Council for Science and Technology: http://www8.cao.go.jp/cstp/english/index.html

[5] Database of Grants-in-Aid for Scientific Research: http://seika.nii.ac.jp/

[6] H. Nomura, M. Maeda, and Y. Mitsuda, M. Negishi, M. Shibayama, M. Nishizawa, Y. Sun, and K. Shigi "Evaluation of Japanese Universities' Research Activity Based on the Number of Awards of Grants-in-Aid for Scientific Research from 1998 to 2002 - I. Law, Economics and Literature - ," NII Technical Report, NII2003-007J, Nov. 2003 (in Japanese).

[7] H. Nomura, M. Maeda, and Y. Mitsuda, M. Negishi, M. Shibayama, M. Nishizawa, Y. Sun, and K. Shigi, "Evaluation of Japanese Universities' Research Activity Based on the Number of Awards of Grants-in-Aid for Scientific Research from 1998 to 2002 - II. Science, Engineering and Agriculture -," NII Technical Report, NII-2004-001J, Jan. 2004 (in Japanese).

[8] H. Nomura, M. Maeda, and Y. Mitsuda, M. Negishi, M. Shibayama, M. Nishizawa, Y. Sun, and K. Shigi, "Evaluation of Japanese Universities' Research Activity Based on the Number of Awards of Grants-in-Aid for Scientific Research from 1998 to 2002 - III. Medical Science, Dentistry, Pharmacy and Nursing —," NII Technical Report, NII-2004-002J, Jan. 2004 (in Japanese).

[9] H. NOMURA, M. MAEDA, and Y. MITSUDA, M. NEGISHI, M. SHIBAYAMA, M. NISHIZAWA, Y. Sun, and K. Shigi, "Evaluation of Japanese Universities' Research Activity Based on the Number of Awards of Grants-in-Aid for Scientific Research from 1998 to 2002 — IV. Interdisciplinary _," NII Technical Report, NII-2004-003J, Feb. 2004 (in Japanese).

[10] H. Nomura, M. Maeda, and Y. Mitsuda, M. Negishi, M. Shibayama, M. Nishizawa, Y. Sun, and K. Shigi, 
"Evaluation of Japanese Universities' Research Activity Based on the Number of Awards of Grants-in-Aid for Scientific Research from 1998 to 2002 - V. Grantsin-Aid for JSPS Fellows _-, NII Technical Report, NII2004-004J, Feb. 2004 (in Japanese).

[11] H. Nomura, M. Maeda, and Y. Mitsuda, M. Negishi, M. Shibayama, M. Nishizawa, Y. Sun, and K. Shigi, "Evaluation of Japanese Universities' Research Activity Based on the Number of Awards of Grants-in-Aid for Scientific Research from 1998 to 2002 - VI. Largescaled Project Funds -," NII Technical Report, NII2004-005J, Mar. 2004 (in Japanese).

[12] H. Nomura, M. Maeda, Y. Mitsuda, and I. Maebashi, M. Negishi, M. Shibayama, M. Nishizawa, Y. Sun, and S. Sugita, "Evaluation of Japanese Universities' Research Activity Based on the Number of Awards of Grants-inAid for Scientific Research - 2003 Fiscal Year -I. Humanities and Social Sciences," NII Technical Report, NII-2005-002J, Mar. 2005 (in Japanese).

[13] H. Nomura, M. Maeda, Y. Mitsuda, and I. Maebashi, M. Negishi, M. Shibayama, M. Nishizawa, Y. Sun, and S. Sugita, "Evaluation of Japanese Universities' Research Activity Based on the Number of Awards of Grants-inAid for Scientific Research - 2003 Fiscal Year - II. Sciences and Engineering," NII Technical Report, NII2005-004J, Mar. 2005 (in Japanese).

[14] H. Nomura, M. Maeda, Y. Mitsuda, and I. Maebashi, M. Negishi, M. Shibayama, M. Nishizawa, Y. Sun, and S. Sugita, "Evaluation of Japanese Universities' Research Activity Based on the Number of Awards of Grantsin-Aid for Scientific Research - 2003 Fiscal Year III. Biosciences," NII Technical Report, NII-2005-006J, Mar. 2005 (in Japanese).

[15] H. Nomura, M. Maeda, Y. Mitsuda, and I. Maebashi, M. Negishi, M. Shibayama, M. Nishizawa, Y. Sun, and S. Sugita, "Evaluation of Japanese Universities' Research Activity Based on the Number of Awards of Grantsin-Aid for Scientific Research - 2003 Fiscal Year IV. Interdisciplinary and New Area and Large-scaled Project Funds," NII Technical Report, NII-2005-007J, Mar. 2005 (in Japanese).

[16] Y. Mitsuda, H. Nomura, M. Maeda, and I. Maebashi, M. Negishi, M. Shibayama, M. Nishizawa, Y. Sun, and S. Sugita, "Evaluation of Japanese Universities' Research Activity Based on the Number of Awards of Grants-inAid for Scientific Research - 2003 Fiscal Year -V. Grant-in-Aid for JSPS Fellows," NII Technical Report, NII-2005-008J, Apr. 2005 (in Japanese).

[17] H. Nomura, M. Maeda, Y. Mitsuda, and I. Maebashi, Evaluation of Japanese Universities' Research Activity Based on the Number of Awards of Grants-in-Aid for Scientific Research from 1998 to 2002, Keibundha, 2005 (in Japanese).

[18] H. Nomura, M. Maeda, Y. Mitsuda, and I. Maebashi, Japanese Universities' Research Activity - Number of
Awards of Grants-in-Aidfor Scientific Research in 2003, Transart, 2006 (in Japanese).

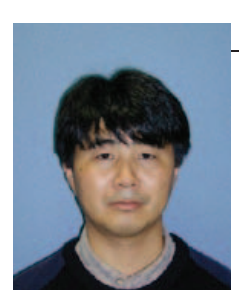

\section{Masaki NISHIZAWA}

Masak HISHIZAWA is Associate Professor of Information and Society Research at National Institute of Informatics, Japan (NII) and School of Multidisciplinary Sciences, Graduate University for Advanced Studies (SOKENDAI). He has educational background in cosmic-ray physics at Konan University, and earned Doctor(science) degree from Konan University. His recent research topics are scientmetric and bibliometric study of research activities. On one hand, he continues cosmic-ray physics research.

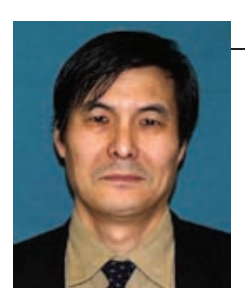

\section{Masamitsu NEGISHI}

Masamitsu NEGISHI is Professor of Information and Society Research at National Institute of Informatics, Japan (NII) and also in charge of Dean, School of Multidisciplinary Sciences, Graduate University for Advanced Studies (SOKENDAI). His research topics cover scientific information databases, electronic library systems and bibliometric study of research trend. He has educational background in economics at Tokyo University, and served its research centers since 1976 as Research Associate and Associate Professor before he joined National Center for Science Information Systems (NACSIS), the predecessor of NII.

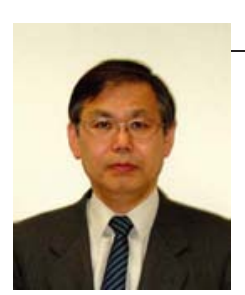

\section{Morio SHIBAYAMA}

Morio SHIBAYAMA received B.E. and M.E. degrees from University of Tokyo in 1975 and 1977, respectively. $\mathrm{He}$ is an associate professor, Information and Society Research Division, National Institutes of Informatics. His current researches are evaluation of research, survey of research environment and identification of creativity in research activities. 


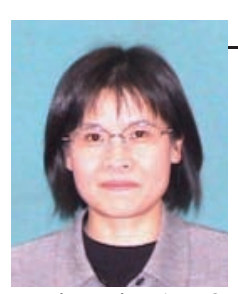

\section{Yuan SUN}

Yuan SUN is an associate professor at the Information and Society Research Division, National Institute of Informatics (NII). She joined the National Center for Science Information Systems (NACSIS) as a research associate in 1992 after finishing her doctoral program at the University of Tokyo. In 1994, she spent 10 months as a visiting professor at the University of Illinois at Urbana-Champaign. Her research interests include bibliometric studies on research evaluations, assessments of R\&D activities, university-industry research linkages in Japan, and measurements of the international flow of science and technology.

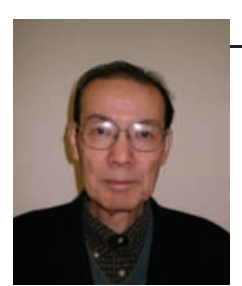

\section{Hiroyasu NOMURA}

Hiroyasu NOMURA received B.S. and M.S. degrees from Nagoya University in 1962 and 1964, respectively, and earned Ph.D. from Nagoya University in 1973. He has been working at Faculty of Engineering, Nagoya University as a Professor since 1973, as the ex-vice-president of Nagoya University from 1996 to 2000, and became Emeritus Professor of Nagoya University in 2000. He joined Tokyo Denki University as a Professor in 2000 and is the vice president of Tokyo Denki University since 2005. His current research interests include Physical Chemistry: liquid and solution.

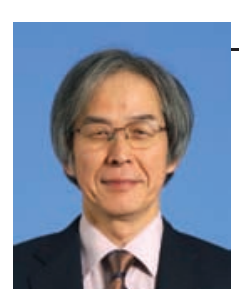

\section{Masafumi MAEDA}

Masafumi MAEDA earned Ph.D. in Metallurgy from the University of Tokyo in 1981. He has been working at Faculty of Engineering, the University of Tokyo as a Research Associate since 1981, and at Institute of Industrial Science, the University of Tokyo as a Professor of Department of Materials and Environment Sciences since 1984. He is Director General, Institute of Industrial Science, the University of Tokyo since 2005, Director, International Research Center for Sustainable Materials, Institute of Industrial Science, the University of Tokyo since 2004. His current research interests are on recycling various metals and silicon. Topics of recycling he is working are: refining of metallurgical grade silicon to semiconductor grade, recovery of hydrogen absorbing metal compounds from $\mathrm{Ni}-\mathrm{H}$ rechargeable buttery for hybrid cars and electrochemical reactions of platinum-metal compounds for recycling. Thermodynamics measurements of metal and oxide compounds by means of high temperature mass spectrometry are another major topics.

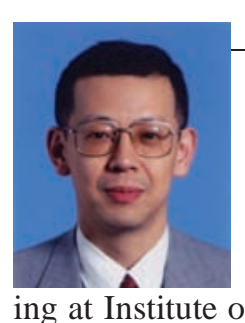

\section{Yoshitaka MITSUDA}

Yoshitaka MITSUDA recieved a B.Eng. and M.Eng. degrees in Metallurgy from the University of Tokyo in 1984 and 1986, respectively. He earned Ph.D. from the University of Tokyo in 1989. He has been working at Institute of Industrial Science, the University of Tokyo as a Professor of Department of Materials and Environment Sciences since 1991. His current research areas include plasma chemistry for thin film deposition and politics on higher education. 
Appendix 1 Research field classification table including the top and second level research areas for application in TY 2002.

\begin{tabular}{|c|c|c|}
\hline $\begin{array}{c}\text { Research Area } \\
\text { (Top level) }\end{array}$ & $\begin{array}{l}\text { Subfield } \\
\text { (Level 2) }\end{array}$ & $\begin{array}{c}\text { No. of sub-area } \\
\text { (leve| 3) }\end{array}$ \\
\hline \multirow{4}{*}{ Arts/Humanities } & Philosophy & 8 \\
\hline & Psychology/Sociology/Pedagogy/Cultural Anthropology & 5 \\
\hline & History & 4 \\
\hline & Literature & 9 \\
\hline Law & Law & 7 \\
\hline Economics & Economics & 8 \\
\hline \multirow{7}{*}{ Science } & Mathematics & 5 \\
\hline & Astronomy & 1 \\
\hline & Physics & 5 \\
\hline & Earth Science & 7 \\
\hline & Chemistry & 6 \\
\hline & Biology & 6 \\
\hline & Anthropology (including Physiological Anthropology) & 1 \\
\hline \multirow{9}{*}{ Engineering } & Applied Physics/Engineering Basics & 5 \\
\hline & Machanical Engineering & 7 \\
\hline & Electric and Electronic Engineering & 7 \\
\hline & Civil Engineering & 6 \\
\hline & Architectonics & 4 \\
\hline & Material Engineering & 6 \\
\hline & Process Engineering & 5 \\
\hline & Industrial Chemistry & 6 \\
\hline & Integrated Engineering & 4 \\
\hline \multirow{8}{*}{ Agriculture } & Agriculture & 5 \\
\hline & Agricultural Chemistry & 4 \\
\hline & Forestry & 2 \\
\hline & Fishery studies & 2 \\
\hline & Agronomy & 1 \\
\hline & Agricultural Engineering & 3 \\
\hline & Livestock Science/Veterinary Medicine & 4 \\
\hline & Boundary Agriculture & 2 \\
\hline \multirow{9}{*}{ Medicine } & Physiology & 6 \\
\hline & Pathology & 6 \\
\hline & Social Medicine & 3 \\
\hline & Internal Medicine & 14 \\
\hline & Surgery & 12 \\
\hline & Dentistry & 8 \\
\hline & Pharmacy & 5 \\
\hline & Medicine in General & 4 \\
\hline & Nursing Science & 2 \\
\hline \multirow{18}{*}{ Interdisciprinary Studies } & $\begin{array}{l}\text { History of Science and Technology (including Sociology of } \\
\text { Sciense/Basic Theory of Science and Technology) }\end{array}$ & 1 \\
\hline & Physical Education & 1 \\
\hline & Geography & 2 \\
\hline & Domestic Science & 2 \\
\hline & Cultural Asset Science & 1 \\
\hline & Science Education/Curriculum Education & 4 \\
\hline & Statistical Science & 1 \\
\hline & Information Science & 3 \\
\hline & Social System Engineering & 1 \\
\hline & Natural Disaster Science & 1 \\
\hline & Plasma Science and Technology & 1 \\
\hline & Energy Studies & 3 \\
\hline & Environmental Science & 3 \\
\hline & Biological Chemistry & 3 \\
\hline & Basic Biology & 4 \\
\hline & Neuroscience (including Brain Science) & 4 \\
\hline & Laboratory Animal Studies & 1 \\
\hline & Biomedical Engineering/Biological Material Studies & 1 \\
\hline General Studies & General Studies & 1 \\
\hline
\end{tabular}


Appendix 2 Research field classification tables for application in FY 2003.

\begin{tabular}{|c|c|c|}
\hline \multicolumn{3}{|c|}{ [Interdisciplinary and New Area] } \\
\hline Research Area & Subfield & No. of sub-area \\
\hline \multirow{10}{*}{ General Area } & Informatics & 11 \\
\hline & Neuroscience & 4 \\
\hline & Laboratory Animal Science & 1 \\
\hline & Human Medical Engineering & 3 \\
\hline & Health/Sports Science & 3 \\
\hline & human Iife science & 2 \\
\hline & Science Education/Educational Technology & 2 \\
\hline & Sociology/History of Sience and Technology & 1 \\
\hline & Cultural Asset Science & 1 \\
\hline & Geography & 1 \\
\hline \multirow{8}{*}{ Complex New Area } & Enviroment Studies & 4 \\
\hline & Nano/Micro Science & 3 \\
\hline & Society/Safety System Science & 2 \\
\hline & Genome Science & 2 \\
\hline & Living Organism Molecular Science & 1 \\
\hline & Resource Maintenance Studies & 1 \\
\hline & Area Studies & 1 \\
\hline & Gender Studies & 1 \\
\hline
\end{tabular}

\begin{tabular}{|c|l|c|}
\multicolumn{2}{l}{ [Humanities and Social Sciences] } \\
\hline Research Area & \multicolumn{1}{|c|}{ Subfield } & No. of sub-area \\
\hline \multirow{5}{*}{ Humanities } & Philosophy & 6 \\
\cline { 2 - 3 } & Literature & 3 \\
\cline { 2 - 3 } & Linguistics & 5 \\
\cline { 2 - 3 } & History & 5 \\
\cline { 2 - 3 } Social Science & Human Geography & 1 \\
\cline { 2 - 3 } & Cultural Anthropology & 7 \\
\hline & Law & 7 \\
\cline { 2 - 3 } & Politics & 3 \\
\cline { 2 - 3 } & Economics & 2 \\
\cline { 2 - 3 } & Business Administration & 4 \\
\cline { 2 - 3 } & Sociology & 4 \\
\cline { 2 - 3 } & Psychology & 7 \\
\cline { 2 - 3 } & Pedagogy & 2 \\
\hline
\end{tabular}

[Science and Engineering]

\begin{tabular}{|c|c|c|}
\hline Research Area & Subfield & No. of sub-area \\
\hline \multirow{5}{*}{$\begin{array}{l}\text { Mathematical and Physical } \\
\text { science }\end{array}$} & Mathematics & 5 \\
\hline & Astronomy & 1 \\
\hline & Physics & 6 \\
\hline & Earth Planet Science & 7 \\
\hline & Plasma Science & 1 \\
\hline \multirow{3}{*}{ Chemistry } & Basic Chemistry & 3 \\
\hline & Compound Chemistry & 6 \\
\hline & Material Chemistry & 4 \\
\hline \multirow{8}{*}{ Engineer ing } & Applied Physics/Engineering Basics & 5 \\
\hline & Mechanical Engineering & 7 \\
\hline & Electric and Electronic Engineering & 7 \\
\hline & Civil Engineering & 6 \\
\hline & Architectonics & 4 \\
\hline & Material Science & 6 \\
\hline & Process Engineering & 4 \\
\hline & Integrated Engineering & 7 \\
\hline
\end{tabular}

[Biosciences]

\begin{tabular}{|c|c|c|}
\hline Research Area & Subfield & No. of sub-area \\
\hline \multirow{3}{*}{ Biology } & Basic Biology & 6 \\
\hline & Biological Science & 7 \\
\hline & Anthropology & 2 \\
\hline \multirow{8}{*}{ Agr icul ture } & Agricul ture & 5 \\
\hline & Agricultural Chemistry & 5 \\
\hline & Forestry & 2 \\
\hline & Fishery Studies & 2 \\
\hline & Agronomy & 1 \\
\hline & Agricul tural Engineering & 3 \\
\hline & Livestock Science/Veterinary Science & 5 \\
\hline & Boundary Agricul ture & 2 \\
\hline \multirow{8}{*}{$\begin{array}{l}\text { Medicine, Dentistry, and } \\
\text { Pharmacy }\end{array}$} & Pharmacy & 6 \\
\hline & Basic Medicine & 13 \\
\hline & Boundary Medicine & 3 \\
\hline & Social Medicine & 3 \\
\hline & Internal Clinical Medicine & 15 \\
\hline & Surgical Clinincal Medicine & 13 \\
\hline & Dentistry & 9 \\
\hline & Nursing Science & 3 \\
\hline
\end{tabular}

